\title{
Neurochemistry of Schizophrenia: The Contribution of Neuroimaging Postmortem Pathology and Neurochemistry in Schizophrenia
}

B. Dean*

NHMRC Senior Research Fellow, the Florey Institute of Neuroscience and Mental Health, Victoria, Australia and the Department of Psychiatry, the University of Melbourne, Victoria, Australia

\begin{abstract}
The advent of molecular neuroimaging has greatly impacted on understanding the neurochemical changes occurring in the CNS from subjects with psychiatric disorders, especially schizophrenia. This review focuses on the outcomes from studies using positron emission tomography and single photon emission computer tomography that have measure levels of neurotransmitter receptors and transporters in the CNS from subjects with schizophrenia. One outcome from such studies is the confirmation of a number of findings using postmortem tissue, but in the case of neuroimaging, using drug naïve and drug free subjects. These findings add weight to the argument that findings from postmortem studies are not an artifact of tissue processing or a simple drug effect. However, there are some important unique findings from studies using neuroimaging studies. These include evidence to suggest that in schizophrenia there are alterations in dopamine synthesis and release, which are not accompanied by an appropriate down-regulation of dopamine D2 receptors. There are also data that would support the notion that decreased levels of serotonin $2 \mathrm{~A}$ receptors may be an early marker of the onset of schizophrenia. Whilst there is a clear need for on-going development of neuroimaging ligands to expand the number of targets that can be studied and to increase cohort sizes in neuroimaging studies to give power to the analyses of the resulting data, current studies show that existing neuroimaging studies have already extended our understanding of the underlying pathophysiology of psychiatric disorders such as schizophrenia.
\end{abstract}

Keywords: Schizophrenia, Neuroimaging, Dopamine, Serotonin, Muscarinic, Glutamate, Cannabinoid.

\section{INTRODUCTION}

The advent of molecular neuroimaging has opened up the possibility of studying changes in the molecular structure of the human CNS in the living, allowing new insights into potential pathophysiological processes in subjects with disorders of the CNS [1]. Thus, at one level, these technologies have given the capability to confirm and expand findings from postmortem CNS studies, which had been the only approach to studying molecular changes in the brain prior to the advent of molecular neuroimaging. However, in psychiatry, neuroimaging of the molecular cytoarchitecture of the human CNS has also provided unique opportunities to i) study people in a drug naïve and drug free state and ii) delve into dynamic processes occurring in the human CNS that cannot be studied in postmortem tissue. This review will focus on how molecular neuroimaging has influence our understanding of changes in CNS neurochemistry in people with psychoses, with a particular focus on schizophrenia, where molecular imaging has been extensively utilized to understand the pathophysiology of that disorder.

It is now widely accepted that many psychiatric disorders manifest in individuals with a genetic predisposition with progress towards the frank disorder being triggered by encounters with as yet to be established environmental factors $[2,3]$. In the case of schizophrenia, such complex interactions

*Address correspondence to this author at the The Florey Institute for Neuroscience and Mental Health, The Kenneth Myer Building, Genetics Lane, The University of Melbourne, Victoria 3010, Australia; Tel: 613-83443786; Fax: 613-9035-3103; Email: anddali@unimelb.edu.au between variations in the human gene sequence and the environment has led to the suggestion that that disorder may be a disorder restricted to humans $[4,5]$. This logic strongly supports the argument that uncovering the underlying pathophysiology of the disorder requires the on-going and extensive study of the human CNS. Significantly, there are now numerous studies that have shown that neurochemical pathways in the human CNS are affected by the pathophysiology of disorders such as schizophrenia $[6,7,8]$ and bipolar disorder [9]. It is therefore not surprising that the advent of neuroimaging techniques saw these technologies used to study neurochemical markers in the brains of people with psychiatric disorders, in particular neurotransmitter receptors and transporters. This review will particularly focus on how neuroimaging studies have complimented and expanded findings using postmortem CNS to increase our understanding of the pathophysiology of psychotic disorders. It will also highlight how molecular neuroimaging of neurotransmitter systems has given new data on potential causes of psychiatric disorders such as schizophrenia. This review does not include other important neuropsychopharmacological based studies using neuroimaging techniques to understand how drug receptor occupancy in the living human CNS affects therapeutic response and side-effect profiles.

\section{NEUROIMAGING AND THE DOPAMINE HY- POTHESIS OF SCHIZOPHRENIA}

The early availability of ligands that targeted receptors enabled these important molecules to be imaged in the CNS using single-photon emission computed tomography 
(SPECT) or positron emission tomography (PET). These technologies were first used in psychiatry to challenge the long standing dopamine hypothesis of schizophrenia that argued that over-activity of dopaminergic pathways contributed to the pathophysiology of schizophrenia [10].

\subsection{Findings on Dopamine-D2 Like Receptors}

Studies on the human genome had shown that there were a family of 5 dopamine receptors, all of which are expressed in the human CNS [11]. However, ligands that have been developed for molecular neuroimaging can only delineate these receptors into two major sub-classes, the dopamine D2-like receptors comprising of the dopamine D2, D3 and D4 receptors (DADR2) and the dopamine D1-like receptors, made up of the dopamine D1 and D5 receptors (DADR1). It has long been recognized that DADR2 were critical to the therapeutic benefits obtained when using antipsychotic drugs [12] and, it was proposed, to the pathophysiology of schizophrenia [7]. Hence initial studies of neurotransmitter systems in schizophrenia focused on this important dopaminergic marker in the dopamine rich region of the human CNS, the caudate nucleus.

The first study using PET to measure DADR2 in schizophrenia showed a $151 \%$ and $161 \%$ increase in $(3-N$ $\left[{ }^{11} \mathrm{C}\right]$ methyl)spiperone $\left(\left[{ }^{11} \mathrm{C}\right] \mathrm{NMS}\right)$ to the caudate nucleus from drug naïve and antipsychotic drug treated people with the disorder, respectively [13] (Table 1). However, a subsequent study using $\left[{ }^{11} \mathrm{C}\right]$ raclopride to measure DADR2 reported no changes in the levels of radioligand binding in the putamen from drug naïve people with schizophrenia [14]; a finding supported using $\left[{ }^{76} \mathrm{Br}\right]$ bromospiperone to measure DADR2 [15].

Following these initial studies, the majority of studies using $\left[{ }^{11} \mathrm{C}\right] \mathrm{NMS}$ have reported increased binding in the caudate-nucleus from drug naïve and drug free people with schizophrenia [16-19] and in late onset schizophrenia [20]. By contrast, two studies reported no change in the binding of that radioligand in schizophrenia [21, 22]. Studies using $\left[{ }^{11} \mathrm{C}\right]$ raclopride $[21,23,24]$ and $\left[{ }^{76} \mathrm{Br}\right]$ bromospiperone $[25]$ have all reported no significant differences in binding in the caudate-nucleus in drug naïve and drug free people with schizophrenia. The findings of unaltered levels of DADR2 is also supported by studies using single photon emission computer tomography of drug naïve and drug free people with schizophrenia using $\left[{ }^{123} \mathrm{I}\right]$-iodobenzamide as the radioligand [26-30]. Significantly, it has recently reported that the binding of this radioligand was not altered in the CNS of subjects at ultra-high risk for developing schizophrenia [31]. Hence, overall, it would appear that it is most likely that neuroimaging studies support the hypothesis that there is no change in DADR2 in the dopaminergic rich regions of the human CNS associated with schizophrenia.

The conflicting results using different DADR2 ligands in neuroimaging is not novel as studies using postmortem tissue had consistently reported an increased levels of $\left[{ }^{3} \mathrm{H}\right]$ spiperone binding to the caudate-putamen from subjects with schizophrenia $[32,33]$ but this difference was not apparent when $\left[{ }^{3} \mathrm{H}\right]$ raclopride was used at appropriate concentrations for receptor saturation [34]. This suggests that the differences in findings on dopamine DADR2 may be related to methodological considerations and / or the pharmacology of the radioligands used.

DADR2 are most predominant in the caudate-nucleus but can be detected in other regions of the human central nervous system [35] and a few neuroimaging studies have been carried out to determine if DADR2 are altered in regions of the CNS other than the caudate-putamen. Two of these studies have failed to provide any evidence for changed dopamine DADR2 in the cortex of people with schizophrenia [24, 29]. By contrast, a PET study using $\left[{ }^{18} \mathrm{~F}\right]$ fallypride reported a decrease in DADR2 in the anterior cingulate in people with schizophrenia [36] and a SPECT study using [ $\left.{ }^{123} \mathrm{I}\right]$ epidepride reported that DADR2 were decreased in the left and right temporal cortex of people with schizophrenia [37]. Hence, it is possible that there are region-specific changes in the levels of DADR2 in regions other than the caudate nucleus in people with schizophrenia. This notion is support by some postmortem studies that also suggest there may be regionspecific changes in DADR2 in the cortex of subjects with schizophrenia [38-40].

The notion of region-specific changes in DADR2 in people with schizophrenia becomes even more refined based on studies in the thalamus. Thus, one study using PET and $\left[{ }^{18} \mathrm{~F}\right]$ fallypride reported a decrease in binding in right medial thalamus in schizophrenia without finding any change in binding in the left thalamus [24]. A second study using the same radioligand failed to show a change in binding across the entire thalamus but reported a decrease in binding in the left medial dorsolateral nucleus $(-18 \%)$ and pulvinar $(-18 \%)$ [41]. Finally, a study using $\left[{ }^{11} \mathrm{C}\right]$ raclopride reported a generalized decrease in binding in the right thalamus but not left thalamus from subjects with the disorder [42]. These data suggest the changes in DADR2 in the CNS from subjects with schizophrenia are complex and will require studies of larger populations before the hypothesis that changes in DADR2 in the CNS from people with schizophrenia can be thoroughly tested.

Two studies have measured DADR2 in the CNS of subjects with schizophrenia and bipolar disorder (BPD) to determine whether changes in receptor density were associated with diagnoses or symptom profiles (Table 1). These studies reported an increase in $\left[{ }^{11} \mathrm{C}\right] \mathrm{NMS}$ binding in drug naïve people with schizophrenia, drug naïve people with BPD and drug free people with BPD [18, 19]. However, both studies suggested that levels of the binding of that radioligand was not altered in people with BPD who did not have psychotic symptoms, suggesting the increase in DADR2 is associated with a psychotic state rather than a specific diagnoses. These data must be interpreted with caution as the number of nonpsychotic people with BPD was very small $(n=7)$ and interpreting the meaning of changes in $\left[{ }^{11} \mathrm{C}\right] \mathrm{NMS}$ is not straight forward.

In what are now extensive studies of DADR2 in the human CNS, it is significant that fewer females have been included (Table 1). However, no study has identified differences in binding with gender, a notion that was confirmed by a study specifically designed to address that question [30]. By contrast, some studies have reported that levels of dopamine DA-D2 receptor decreased with age in the frontal [24] and temporal cortices [24, 37] and striatum [19]. These data 
add to findings from other neuroimaging studies using multiple ligands $[19,43,44]$ and studies using postmortem tissue $[45,34]$ that have shown a loss of dopamine DA-D2 with aging in multiple CNS regions. Recent data has shown that changes in gene expression change with increasing duration of illness in the cortex of people with schizophrenia [46, 47] and that some of these may represent an accelerated aging process in people with the disorders [48]. This means that aging is an important confound that must be carefully controlled in all studies of DADR2 in the human CNS.

\subsection{Findings on Dopamine-D1 Like Receptors}

The DADR1 are the family of DADRs that do not have a high affinity for antipsychotic drugs but are critical in the physiological effects of dopamine in the CNS [49]. The DADR1 is the predominant family of dopamine receptors in the human cortex [50]. It is therefore significant that a study that failed to show a change in ligand binding to DADR2 in people with schizophrenia found that $\left[{ }^{11} \mathrm{C}\right] \mathrm{SCH} 23390$ binding to DADR1 was unchanged in the striatum but decreased by $15 \%$ and $20 \%$ in the prefrontal cortex of drug naïve and drug free people with the disorder, respectively [51] (Table 1). This study also reported that the decrease in DADR1 in the cortex of people with schizophrenia was inversely related to levels of negative symptomatology.

The notion of decreased DADR1 in the CNS from subjects with schizophrenia is supported by a study using $\left[{ }^{11} \mathrm{C}\right] \mathrm{SCH} 23390$ and [ $\left.11 \mathrm{C}\right] \mathrm{NNC} 112$, both of which bind to DADR1, which reported decreases in binding in frontal cortex $(-29 \%,-32 \%)$, anterior cingulate $(-25 \%,-28 \%)$, temporal cortex $(-30 \%,-28 \%)$ and striatum $(-21 \%,-22 \%)$ in people with the disorder [52]. However, it is notable that this study did not find changes in binding in the striatum and was carried out in people who had received antipsychotic drug treatment and had recently been switched to sulpride. The effect of drug treatment could be significant given a recent study using drug naïve, drug free and treated people with schizophrenia suggested that ligand binding to DADR1 was restricted to, and increased in, the dorsolateral prefrontal cortex $(32 \%)$, occipital frontal cortex $(31 \%)$ and medial frontal cortex $(22 \%)$ from the drug naïve subjects [53]. These data added to a previous study by this group that reported an increase in ligand binding to DADR1 in a mix of drug naïve and chronic drug-free people with schizophrenia [54]. Finally, the issue of the status of DADR1 levels in subjects with schizophrenia is further clouded by a study reporting no change in $\left[{ }^{11} \mathrm{C}\right] \mathrm{SCH} 23390$ binding to DADR1 in multiple cortical regions from people with schizophrenia [55].

The disparate results on DADR1 from people with schizophrenia reflect data obtained from postmortem studies that have reported unchanged (striatum [35, 56, 57]; cortex [40]) and increased (cortex [58,59]) levels of that receptor in the CNS from subjects with schizophrenia. In addition, the potential for antipsychotic drugs to be a confounded is supported by reports that treating rats with such drugs causes changes in DADR1 which vary with drug, drug dose, treatment duration and CNS region [60-63]. It would therefore seem that more studies on DADR1 in drug naïve subjects with schizophrenia are needed to give a clearer view on the status of that family of receptors in the CNS of subjects with disorder.

\subsection{Findings on the Dopamine Transporter}

The dopamine transporter (DAT) is an important component of the dopaminergic system that is present on presynaptic dopaminergic neurons and acts to take up secreted dopamine back into the pre-synaptic neuron and has a critical role in regulating dopamine levels in the synapse [64]. Significantly, the great majority of neuroimaging studies suggest there is no change in the levels of DAT in the striatum from subjects with schizophrenia [65-72] (Table 1). However, one study found no changes in DAT in the striatum in a group of people with schizophrenia in the first episode [65] but did find a decrease $(-11.5 \%)$ in levels of the transporter in the same CNS region from people in the chronic stage of the illness [73]. This raised the possibility that changes in DAT may appear with disease progression or because of treatment with antipsychotic drugs. However, another study has reported a small decrease $(-9 \%)$ in levels of DAT in a group of drug naïve people with schizophrenia [74] and a subsequent study from this group showed that levels of DAT were significantly decreased in drug naïve subjects $(-12 \%)$ and remained so after 4 weeks of antipsychotic drug treatment $(-9 \%)$ [75]. This data were consistent with DAT been changed early after the onset of schizophrenia and that this change was not reversed by acute antipsychotic drug treatment. To cloud the issue further, another study reported a $50 \%$ increase in DAT in people with schizophrenia compared to controls and this compared to a $70 \%$ loss of DAT in a group of people with Parkinson's disease [76] . Finally, one study that failed to find a change in DAT in the striatum of drug naïve and drug free people with schizophrenia did report a $28 \%$ increase in the transporter in the thalamus from the same cohort. This latter finding could be indicating there may be region-specific changes in DAT, as well as dopamine receptors, in schizophrenia.

The majority of postmortem studies agree with results from neuroimaging that report levels of the dopamine transporter to be unchanged (striatum $[35,77,78]$; cortex [40]) in tissue from subjects with schizophrenia with only one study suggesting a decrease in the transporter in the striatum [79]. Similarly, studies on the effects of antipsychotic drug treatment have failed to show such treatments change the levels of DAT [80]. Therefore from both neuroimaging and postmortem CNS studies it seems reasonable to conclude that there are not large changes in dopamine transporters in the striatum of people with schizophrenia and therefore changes in dopamine transporter levels are not likely be making a significant contribution to changes in extra-synaptic dopamine in people with the disorder.

\subsection{The Dynamics of Dopamine Synthesis and Release}

One aspect of neuroimaging studies that cannot be replicated using postmortem CNS is measuring parameters relating to the dynamics of neurotransmitter synthesis and release in the human CNS. In the case of dopamine, rates of neurotransmitter synthesis can be inferred by measuring [18F]fluorodopamine influx [81]. Rates of dopamine release have been estimated as the decrease in available ligand binding sited on the DADR2 due to the displacement by dopamine after a stimulus by a dopamine releasing agent such as amphetamine [82]. 
The outcome from studies on dopamine synthesis have been complex with the initial study reporting that the $[18 \mathrm{~F}]$ fluorodopamine influx constant $(\mathrm{K}$, ) in putamen was $15 \%$ higher in people with schizophrenia compared to controls, with changes in caudate being smaller and lateralized to the left caudate [81] (Table 1). In a follow up study, this group confirmed that $[18 \mathrm{~F}]$ fluorodopamine uptake was increased in striatum in people with schizophrenia and that the $\mathrm{Ki}$ for [18F]fluorodopamine uptake was shown to have a negative correlation with depressive symptoms [83]. These findings were partly confirmed by a study which reported a significant decrease $(-15 \%)$ in tracer uptake in ventral striatum with the same study reporting an increased $(21 \%)$ in [18F]fluorodopamine uptake in posterior cingulate in people with the disorder [84]. Ongoing studies continue to suggest there are changes in dopamine synthesis in the CNS of subjects with schizophrenia. Hence, one study showed that the intrinsic clearance of [18F]fluorodopamine is $20-50 \%$ greater in the CNS of people with schizophrenia and there was also a $75-90 \%$ increase in the fractional rate constant for [18F]fluorodopamine elimination in people with the disorder [85]. Finally, the changes in [18F]fluorodopamine uptake have been used along with an Artificial Network Model to identify people with schizophrenia with $89 \%$ accuracy in a study where controls could be identified with a 94\%-[86]. If these data are correct they would suggest that, not only do people with schizophrenia have changes in dopamine synthesis but that these changes may be useful as a diagnostic biomarker.

The first study on amphetamine-induced dopamine release showed that the loss of [123I]iodobenzamide ([123I]IBZM) binding potential, a measure inversely related to levels of dopamine, was significantly greater in the striatum of people with schizophrenia $(-19.5 \pm 4.1 \%)$ compared to that in the control subjects $(-7.6 \pm 2.1 \%)$ [82] (Table 1). These data suggested there was an increased release of dopamine in response to amphetamine in people with the disorder. Further studies have shown the same outcome in drug naïve [87], drug free [88] and a mix of drug-free and treated [89] people with schizophrenia as well as people with schizotypal personality disorder [90].

The new insight into dynamic interactions of the dopaminergic system in the brain provided by neuroimaging seems to be pointing to problems in both the synthesis and release of dopamine in at least schizophrenia. Whilst there was postmortem CNS data that suggested such pre-synaptic problems may exist [8], having a direct confirmation that pre-synaptic processing of dopamine is an issue in schizophrenia is a significant step forward in understanding the pathophysiology of the disorder.

\subsection{Interpreting Changes in Dopamine Pathways in Schizophrenia and Psychoses}

Bringing together neuroimaging studies, that have mainly been carried out in people with schizophrenia, it would appear that there is an increased synthesis and release of dopamine in the striatum of people with the disorder which occurs in that absence of changes in levels of DADR2, DADR1 and DAT. This is a significantly different profile to that found in people who are methamphetamine users who have acute and chronic decreased levels of DADR2 [91] and DAT
[92]. Methamphetamine and other drugs of addiction act to increase release of dopamine in the brain [93] and therefore the changes in the CNS of people who use these drugs are likely to be compensatory mechanisms related to high levels of synaptic dopamine. This notion is partly supported by studies in acute Parkinson's disease, where there are decreased levels of synaptic dopamine [94] and where DADR2 are increased $[95,96]$. Thus, current data would argue that, as well as changes in dopamine synthesis and release, there is a failure to down-regulate DADR2 in people with schizophrenia in the face of high levels of synaptic dopamine. This could suggest that mechanisms that are known to act to down-regulate DADR2 [97] may be affected by the pathophysiology of schizophrenia and / or the drive to a psychotic state.

\section{NEUROIMAGING AND THE SEROTONIN HY- POTHESIS OF SCHIZOPHRENIA}

The serotonin hypothesis of schizophrenia has its basis in the observation that people who have taken lysergic acid show a propensity to experience florid hallucinations [98]. This observation implicates the serotonergic system because lysergic acid binds to a number of serotonin receptors [99] and hence suggests the serotonergic system might be involved in the pathophysiology of psychotic disorders [100].

\subsection{Findings on the Serotonin $2 \mathrm{~A}$ Receptor}

The first serotonergic marker to be studied in people with psychoses was the serotonin $2 \mathrm{~A}$ receptor (5HT2AR). This was probably driven by the fact that a suitable ligand was available, the receptor was recognized as a target for second generation antipsychotic drugs [101] and levels of that receptor had been shown to be decreased in postmortem CNS from people with schizophrenia [102].

The first studies on 5HT2AR were in mixed cohorts of drug naïve and drug free people with schizophrenia and showed no differences in the level of receptor in the CNS of people with the disorder $[103,104,105,106]$ (Table 2; Fig. 1). By contrast, the first report of decreased 5HT2AR ($16 \%$ in the CNS from subjects with schizophrenia was study of a cohort of purely drug naïve people with the disorder [107]. Since this finding, regional selective decreases in levels of 5HT2AR have been reported in people at high risk of developing schizophrenia [108], those in early and late prodromal stages of the disorder [109] and in a relatively large drug naïve cohort of people with the disorder [110]. Contrary to these reports is a study that reported a $40 \%$ increase in levels of 5HT2AR in a cohort of people in their first episode of schizophrenia [111]. Despite this later study, everall current data raises the intriguing possibility that levels of 5HT2AR may be affected early in the progression to frank schizophrenia and the differences present in the CNS in the early stages of the disorder either disappear as part of the pathophysiology of the disorder or due to drug treatment. The change in 5HT2AR early in the progression toward schizophrenia is interesting as it raises the possibility that abnormal levels of 5HT2AR may be present early in life and could therefore be affecting fetal development. This is significant because neurotransmitters systems are critical for normal maturation of the CNS [112] and therefore derangements of molecules such as the 5HT2AR early in life could 
Table 1. Neuroimaging Studies on Dopaminergic Markers in the CNS of People with Psychiatric Disorders Using Positron Emission Tomography and Single Photon Emission Computer Tomography.

\begin{tabular}{|c|c|c|c|c|c|c|c|c|}
\hline Technique & Diagnoses & CNS Region(s) & Radioligand & Treatment Groups & $\mathbf{n}$ & $\mathbf{M}: \mathbf{F}$ & Outcome & Ref. \\
\hline \multirow[t]{3}{*}{ PET } & $\mathrm{Sz}$ & Caudate Nucleus & NMS & $\begin{array}{l}\text { Drug naïve } \\
\text { Treated } \\
\text { Controls }\end{array}$ & $\begin{array}{c}10 \\
5 \\
11\end{array}$ & $\begin{array}{c}8: 2 \\
5: 0 \\
11\end{array}$ & $\begin{array}{l}\text { ヤ } 151 \% \\
\text { ヤ } 161 \%\end{array}$ & {$[13]$} \\
\hline & $\mathrm{Sz}$ & Putamen & RAC & $\begin{array}{l}\text { Drug naïve } \\
\text { Controls }\end{array}$ & $\begin{array}{l}18 \\
20\end{array}$ & $\begin{array}{c}10: 8 \\
10: 10\end{array}$ & No Difference & {$[23]$} \\
\hline & $\mathrm{Sz}$ & Striatum & BROMO & $\begin{array}{l}\text { Drug naïve } \\
\text { Briefly treated } \\
\text { Controls }\end{array}$ & $\begin{array}{c}9 \\
3 \\
12\end{array}$ & $\begin{array}{l}\mathrm{M} \\
\mathrm{M} \\
\mathrm{M}\end{array}$ & No Difference & [196] \\
\hline & $\mathrm{Sz}$ & Striatum & NMS & $\begin{array}{l}\text { Chronic drug naïve } \\
\text { Chronic drug free } \\
\text { Controls }\end{array}$ & $\begin{array}{c}18 \\
7 \\
17\end{array}$ & $\begin{array}{c}\mathrm{Na} \\
\mathrm{Na} \\
13: 4\end{array}$ & ヤ $106 \%$ & {$[16]$} \\
\hline & $\mathrm{Sz}$ & Striatum & NMS & $\begin{array}{l}\text { Late onset } \\
\text { Controls }\end{array}$ & $\begin{array}{l}13 \\
17\end{array}$ & $\begin{array}{l}3 / 10 \\
13 / 4\end{array}$ & ヤ $10 \%$ & {$[20]$} \\
\hline & $\mathrm{Sz}$ & Striatum & $\mathrm{RAC}$ & $\begin{array}{l}\text { Drug naïve } \\
\text { Controls }\end{array}$ & $\begin{array}{l}13 \\
10\end{array}$ & $\begin{array}{l}9: 4 \\
6: 4\end{array}$ & No Difference & {$[21]$} \\
\hline & $\mathrm{Sz}$ & Striatum & NMS & $\begin{array}{l}\text { Drug naïve } \\
\text { Controls }\end{array}$ & $\begin{array}{l}7 \\
7\end{array}$ & $\begin{array}{c}5: 2 \\
7\end{array}$ & No Difference & {$[22]$} \\
\hline & $\mathrm{Sz}$ & $\begin{array}{l}\text { Thalamus, anterior } \\
\text { cingulate, frontal } \\
\text { and temporal corti- } \\
\text { ces }\end{array}$ & FLB & $\begin{array}{l}\text { Drug naïve } \\
\text { Controls }\end{array}$ & $\begin{array}{l}9 \\
8\end{array}$ & $\begin{array}{l}3: 6 \\
4: 4\end{array}$ & $\begin{array}{c}\boldsymbol{\downarrow} \text { in right medial } \\
\text { thalamus. }\end{array}$ & {$[24]$} \\
\hline & $\mathrm{Sz}$ & $\begin{array}{l}\text { Caudate, putamen } \\
\text { and thalamus }\end{array}$ & RAC & $\begin{array}{l}\text { Drug naïve } \\
\text { Controls }\end{array}$ & $\begin{array}{l}18 \\
17\end{array}$ & $\begin{array}{c}9: 9 \\
13: 4\end{array}$ & $\downarrow$ in right thalamus & {$[42]$} \\
\hline & $\begin{array}{l}\text { Sz }+ \text { SzAff }+ \\
\quad \text { SzForm }\end{array}$ & Thalamus & FALL & $\begin{array}{c}\text { Drug naïve + } \\
\text { Drug Free } \\
\text { Controls }\end{array}$ & $\begin{array}{c}12 \\
3 \\
15\end{array}$ & $\begin{array}{l}10: 5 \\
9: 6\end{array}$ & $\begin{array}{c}\text { No change across } \\
\text { entire thalamus but } \\
\downarrow 18 \% \text { in medial } \\
\text { dorsolateral nucleus } \\
\text { and pulvinar. }\end{array}$ & {$[41]$} \\
\hline & Sz and BPD & Striatum & NMS & $\begin{array}{l}\text { Sz drug naïve } \\
\text { BPD drug naïve } \\
\text { BPD drug free } \\
\text { Controls }\end{array}$ & $\begin{array}{c}10 \\
11 \\
3 \\
12\end{array}$ & $\begin{array}{l}8: 2 \\
6: 5 \\
3: 0 \\
9: 3\end{array}$ & $\begin{array}{c}\text { 个 } 147 \% \mathrm{Sz} \\
\text { 个 } 82 \% \mathrm{BPD} \text { with } \\
\text { psychoses }\end{array}$ & {$[18]$} \\
\hline & Sz and BPD & Striatum & NMS & $\begin{array}{c}\text { Drug naïve Sz } \\
\text { Psychotic BPD } \\
\text { Non-psychotic BPD } \\
\text { Controls }\end{array}$ & $\begin{array}{c}22 \\
7 \\
7 \\
24\end{array}$ & $\begin{array}{c}13: 9 \\
4: 3 \\
5: 2 \\
19: 5\end{array}$ & $\begin{array}{c}\text { 个 } 35 \% \mathrm{Sz} \\
\text { 个 } 36 \% \text { BPD with } \\
\text { psychoses. }\end{array}$ & [19] \\
\hline
\end{tabular}


(Table 1) Contd....

Target: Dopamine D2-like Receptors

\begin{tabular}{|c|c|c|c|c|c|c|c|c|}
\hline Technique & Diagnoses & CNS Region(s) & Radioligand & Treatment Groups & $\mathbf{n}$ & $\mathbf{M}: \mathbf{F}$ & Outcome & Ref. \\
\hline \multirow[t]{8}{*}{ SPECT } & $\mathrm{Sz}$ & Striatum & IBMZ & $\begin{array}{l}\text { Drug naïve } \\
\text { Drug free } \\
\text { Controls }\end{array}$ & $\begin{array}{c}17 \\
3 \\
20\end{array}$ & $\begin{array}{c}\mathrm{Na} \\
\mathrm{Na} \\
11: 9\end{array}$ & No Difference & [26] \\
\hline & Sz and Sz-Aff & Basal Ganglia & IBMZ & $\begin{array}{c}\text { Sz drug free } \\
\text { Sz-affect drug free } \\
\text { Controls }\end{array}$ & $\begin{array}{c}19 \\
2 \\
16\end{array}$ & $\begin{array}{c}16: 3 \\
2: 0 \\
11: 5\end{array}$ & No Difference & {$[27]$} \\
\hline & $\mathrm{Sz}$ & Basal Ganglia & IBMZ & $\begin{array}{l}\text { Drug naïve } \\
\text { Controls }\end{array}$ & $\begin{array}{l}23 \\
20\end{array}$ & $\begin{array}{c}11: 12 \\
8: 10\end{array}$ & No Difference & {$[28]$} \\
\hline & $\mathrm{Sz}$ & Temporal cortices & EPI & $\begin{array}{l}\text { Drug naïve } \\
\text { Controls }\end{array}$ & $\begin{array}{l}7 \\
7\end{array}$ & $\begin{array}{l}3: 4 \\
4: 3\end{array}$ & $\begin{array}{l}\boldsymbol{\Downarrow} 29 \% \text { temporal } \\
\text { cortex }\end{array}$ & {$[37]$} \\
\hline & $\mathrm{Sz}$ & $\begin{array}{l}\text { Basal Ganglia / } \\
\text { Frontal cortex }\end{array}$ & IBMZ & $\begin{array}{l}\text { Drug naïve } \\
\text { Drug free } \\
\text { Controls }\end{array}$ & $\begin{array}{c}12 \\
16 \\
0\end{array}$ & $\begin{array}{c}5: 7 \\
13: 3\end{array}$ & No Difference & [29] \\
\hline & $\mathrm{Sz}+\mathrm{SzForm}$ & $\begin{array}{l}\text { Basal Ganglia / } \\
\text { Frontal cortex }\end{array}$ & IBMZ & $\begin{array}{l}\text { Drug naïve } \\
\text { Controls }\end{array}$ & $\begin{array}{c}15 \\
0\end{array}$ & $7: 8$ & No Difference & {$[30]$} \\
\hline & $\mathrm{Sz}$ & & IBMZ & $\begin{array}{l}\text { Drug naïve } \\
\text { Controls }\end{array}$ & $\begin{array}{l}23 \\
10\end{array}$ & $\begin{array}{l}19 / 4 \\
5 / 5\end{array}$ & $\downarrow 15 \%$ striatum & [197] \\
\hline & & & IBMZ & $\begin{array}{l}\text { Ultra High Risk } \\
\text { Controls }\end{array}$ & $\begin{array}{l}14 \\
15\end{array}$ & $\begin{array}{l}12 / 4 \\
13 / 2\end{array}$ & No difference & {$[31]$} \\
\hline
\end{tabular}

Target: Dopamine D2-like Receptors and Dopamine Transporter

\begin{tabular}{|c|c|c|c|c|c|c|c|c|}
\hline & $\mathrm{Sz}$ & Striatum & $\begin{array}{l}\text { IBMZ } \\
\text { TROD }\end{array}$ & $\begin{array}{l}\text { Drug naïve } \\
\text { Controls }\end{array}$ & $\begin{array}{l}11 \\
12\end{array}$ & $\begin{array}{l}6: 5 \\
9: 3\end{array}$ & No difference & {$[68]$} \\
\hline & $\mathrm{Sz}$ & Striatum & $\begin{array}{l}\text { IBMZ } \\
\text { TROD }\end{array}$ & $\begin{array}{l}\text { First episode } \\
\text { Controls }\end{array}$ & $\begin{array}{l}20 \\
12\end{array}$ & $\begin{array}{c}18 / 2 \\
9 / 3\end{array}$ & No difference & [71] \\
\hline \multicolumn{9}{|c|}{ Target: Dopamine D2-like Receptors and Dopamine D1 Receptor } \\
\hline PET & $\mathrm{Sz}$ & $\begin{array}{c}\text { Striatum } \\
\text { Prefrontal cortex } \\
\text { Anterior Cingulate } \\
\text { Temporal cortex }\end{array}$ & $\begin{array}{l}\text { SCH } 23390 \\
\text { NMS }\end{array}$ & $\begin{array}{l}\text { Drug naïve } \\
\text { Drug free } \\
\text { Controls }\end{array}$ & $\begin{array}{c}10 \\
7 \\
18\end{array}$ & $\begin{array}{c}10: 0 \\
7: 0 \\
18: 0\end{array}$ & $\begin{array}{c}\text { Striatum: } \\
\text { No change DA-D1, } \\
\text { No change DA-D2 } \\
\text { Prefrontal cortex: } \\
\text { drug naïve }-15 \% \text {, } \\
\text { drug free }-20 \% \text {. }\end{array}$ & {$[51]$} \\
\hline \multicolumn{9}{|c|}{ Target: Dopamine D1-like Receptors } \\
\hline \multirow[t]{4}{*}{ PET } & $\mathrm{Sz}$ & $\begin{array}{l}\text { Multiple cortical } \\
\text { regions } \\
\text { Striatum } \\
\text { Thalamus }\end{array}$ & $\mathrm{NNC}$ & $\begin{array}{l}\text { Drug naïve } \\
\text { Chronic drug free } \\
\text { Controls }\end{array}$ & $\begin{array}{c}7 \\
9 \\
16\end{array}$ & $\begin{array}{l}3 / 13 \\
5 / 11\end{array}$ & $\begin{array}{l}\uparrow 28 \% \text { dorsolateral } \\
\text { prefrontal cortex }\end{array}$ & {$[54]$} \\
\hline & $\mathrm{Sz}+\mathrm{SzForm}$ & $\begin{array}{c}\text { Multiple cortical } \\
\text { and sub-cortical } \\
\text { regions }\end{array}$ & $\mathrm{SCH} 23390$ & $\begin{array}{l}\text { Drug naïve } \\
\text { Controls }\end{array}$ & $\begin{array}{l}10 \\
10\end{array}$ & $\begin{array}{l}8 / 2 \\
8 / 2\end{array}$ & No differences & {$[55]$} \\
\hline & & & & & & & & [198] \\
\hline & $\mathrm{Sz}$ & & $\begin{array}{l}\mathrm{SCH} 23390 \\
\mathrm{NNC}\end{array}$ & $\begin{array}{c}\text { Treated but } \\
\text { switched to sulpride } \\
\text { Controls }\end{array}$ & 12 & $\begin{array}{l}5 / 1 \\
6 / 6\end{array}$ & $\begin{array}{c}\mathrm{SCH} 23390 \downarrow 29 \% \\
\text { frontal cortex, } 25 \% \\
\text { anterior cingulate, } \\
30 \% \text { temporal cortex } \\
\text { and } 21 \% \text { striatum. } \\
\text { NNC } \downarrow 32 \% \text { frontal } \\
\text { cortex, } 28 \% \text { anterior } \\
\text { cingulate, } 28 \% \text { tem- } \\
\text { poral cortex and } 22 \% \\
\text { striatum. }\end{array}$ & {$[52]$} \\
\hline
\end{tabular}


(Table 1) Contd....

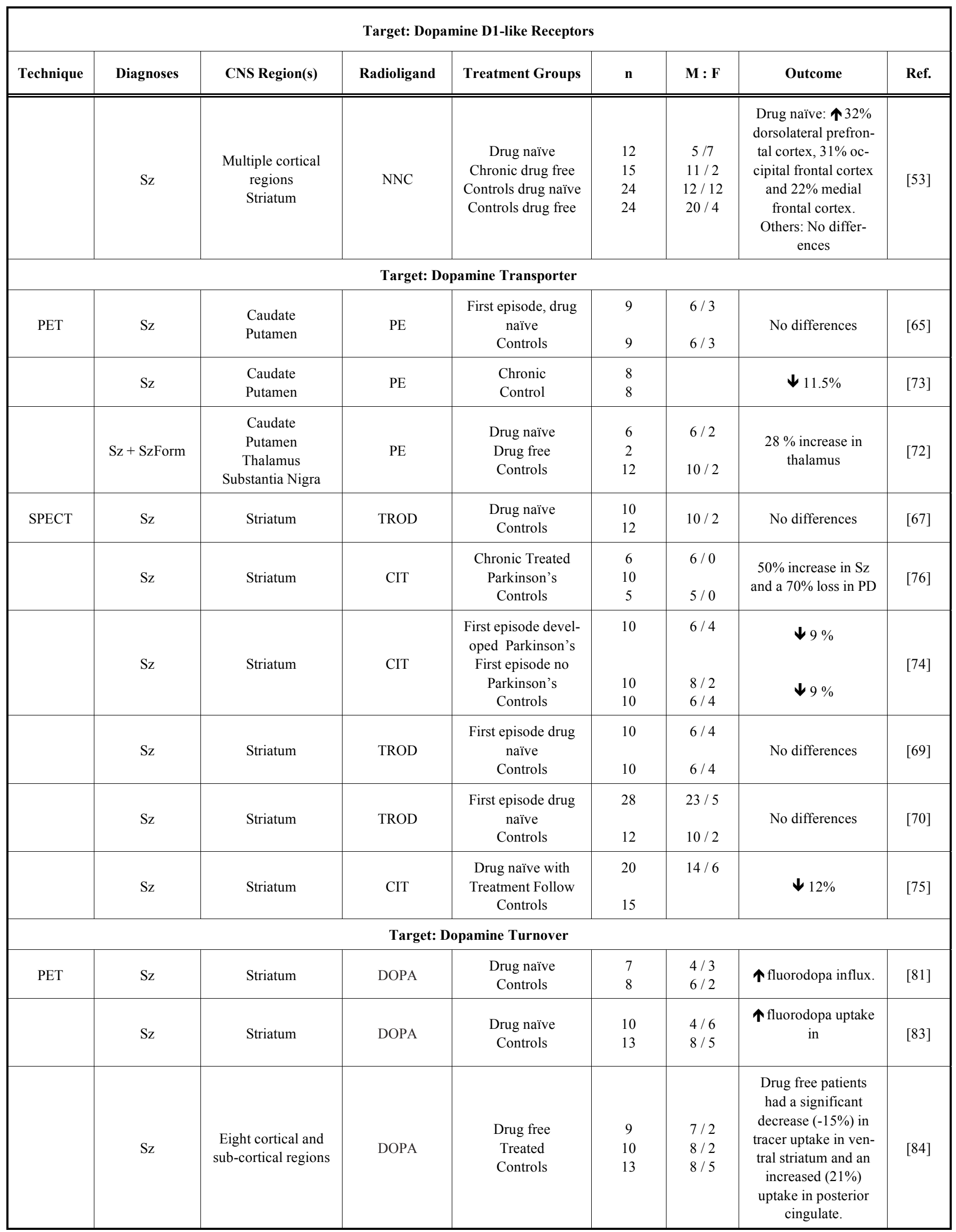


(Table 1) Contd....

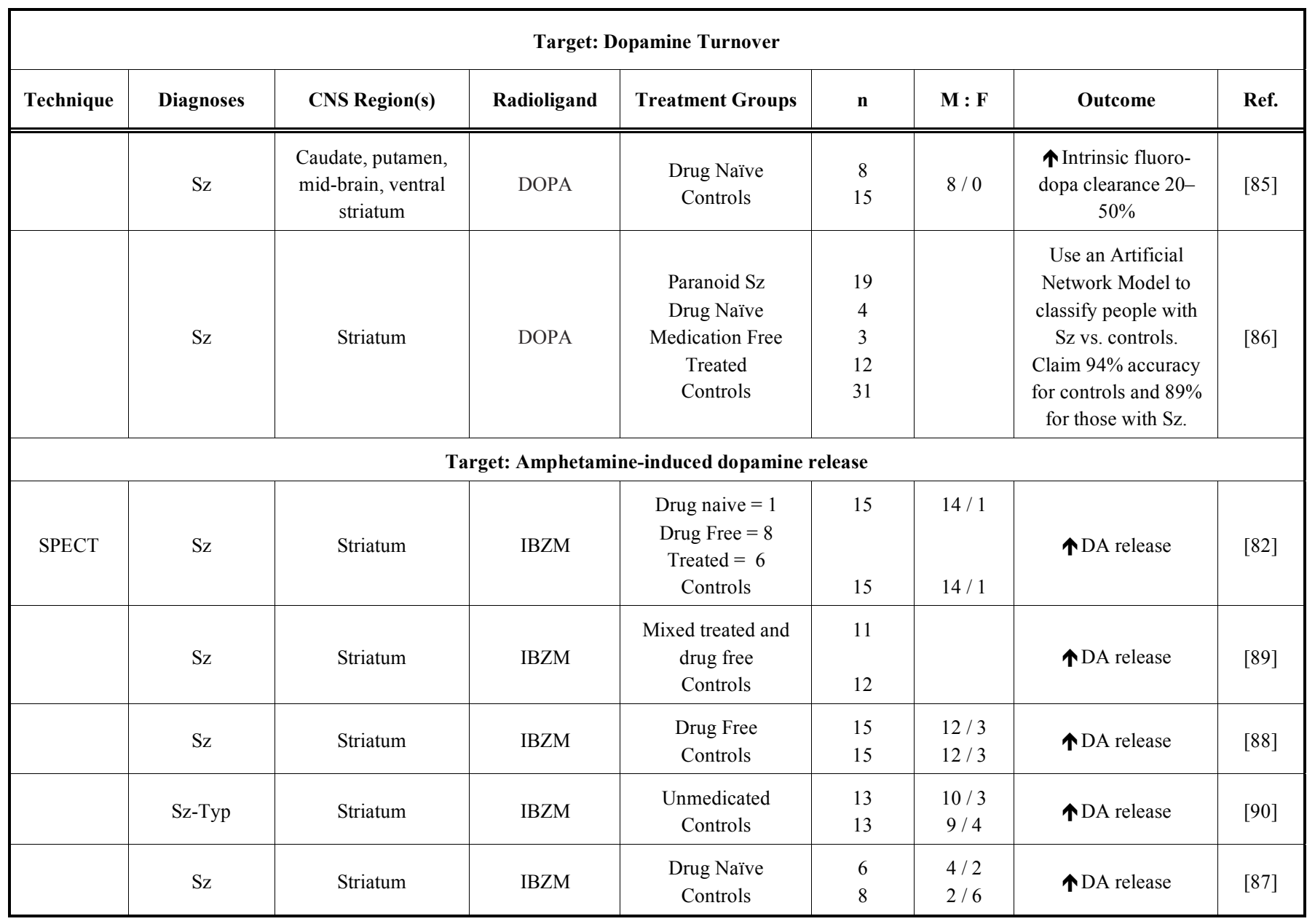

Abbreviations: $\mathrm{BPD}=$ bipolar disorders, $\mathrm{BROMO}=\left[{ }^{76} \mathrm{Br}\right]$ bromospiperone, DOPA $=[18 \mathrm{~F}]$ fluorodopamine, $\mathrm{CIT}=\left[{ }^{123} \mathrm{I}\right] \mathrm{FP}-\mathrm{CIT}$, EPI $=\left[{ }^{123} \mathrm{I}\right]$ epidepride, $\mathrm{FALL}=\left[{ }^{18} \mathrm{~F}\right] \mathrm{Fallypride}, \mathrm{FLP}$ $=\left[{ }^{11} \mathrm{C}\right]$ FLB 457, IBMZ $=\left[{ }^{123} \mathrm{I}\right]$ iodobenzamide, NMS $=\left[{ }^{11} \mathrm{C}\right]$ methylspiperone $, \mathrm{NNC}=\left[{ }^{11} \mathrm{C}\right] \mathrm{NNC} 112, \mathrm{PD}=$ Parkinson's disease, $\mathrm{PE}=\left[{ }^{11} \mathrm{C}\right] \mathrm{PE} 2 \mathrm{I}, \mathrm{RAC}=\left[{ }^{11} \mathrm{C}\right]$ raclopride, $\mathrm{SCH} 23390$ $=\left[{ }^{11} \mathrm{C}\right] \mathrm{SCH} 23390, \mathrm{Sz}=$ Schizophrenia, SzAff $=$ schizoaffective disorder, SzForm $=$ schizophreniform, Sz-Typ $=$ schizotypal personality disorder, TROD $=\left[{ }^{99} \mathrm{mTc}\right] \mathrm{TRODAT}$.

result in abnormal CNS development. It is therefore intriguing to consider whether some of the structural and functional abnormalities that are being detected in specifically in people at high-risk of developing schizophrenia [113-115] may have resulted from alterations in levels of molecules such as the 5HT2AR in their CNS. Such outcomes may gain credence as we get a better understanding of the impact of changes in 5HT2AR on CNS development from genetically modified mice [116].

The majority of postmortem studies using postmortem tissue have also found decreased 5HT2AR in the cortex of subjects with schizophrenia [40, 117-125]. However, in studies using membrane based assays, rather than autoradiography, levels of 5HT2AR have been reported as either unchanged [126] or increased [127] in schizophrenia. It has been suggested that the discrepancies between these findings could be due to separating an endogenous regulator of 5HT2AR binding from the receptor when membranes are washed prior to binding assays being completed [128]. Finally, an autoradiography study of the caudate-putamen suggested that there was an increase in 5HT2R in tissue from subjects with schizophrenia [129]. Taking into account the majority of postmortem studies, there seems to be a growing consensus that 5HT2AR are decreased in the cortex of sub- jects with schizophrenia and, for reasons yet to be explained, this is only detectable early in the progression to frank schizophrenia when using neuroimaging.

Neuroimaging data could also be interpreted as suggesting that decreases in 5HT2AR may disappear after treatment in subjects with schizophrenia. Significantly, studies in rats suggest that acute treatment with antipsychotic drugs that do not directly target the 5HT2AR do not affect CNS levels of the receptor [130-132] whereas treatment with antipsychotic drugs that target the receptor reduce its levels in the rat CNS [130-134]. These data would not support the notion that the apparent decrease in 5HT2AR in drug naïve people with schizophrenia disappears later in the disorder because of antipsychotic drug treatment. This leaves the intriguing possibility that decreased 5HT2AR early in people at high-risk for schizophrenia, when measured by neuroimaging, may provide an indication of a propensity to develop the frank disorder.

\subsection{Findings on other Serotoninergic Markers}

There have been fewer studies using neuroimaging to measure levels of other serotonergic markers in the CNS of subjects with psychoses. Thus, three studies have reported levels of the 5HT1AR are not altered in the CNS of people 
Table 2. Neuroimaging Studies on Non-Dopamine Markers Using Positron Emission Tomography and Single Photon Emission Computer Tomography in Subjects with Psychotic Subjects

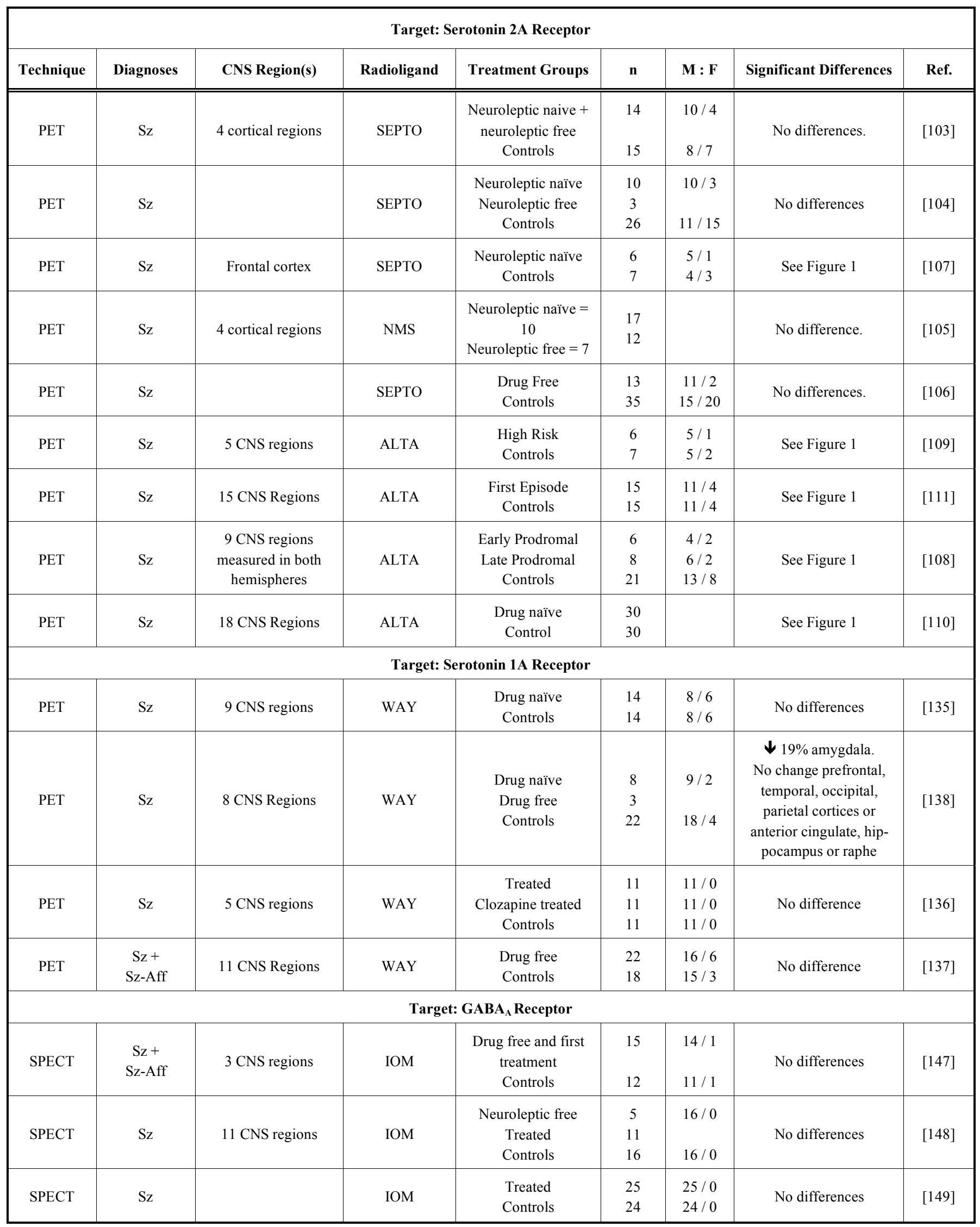


(Table 2) Contd....

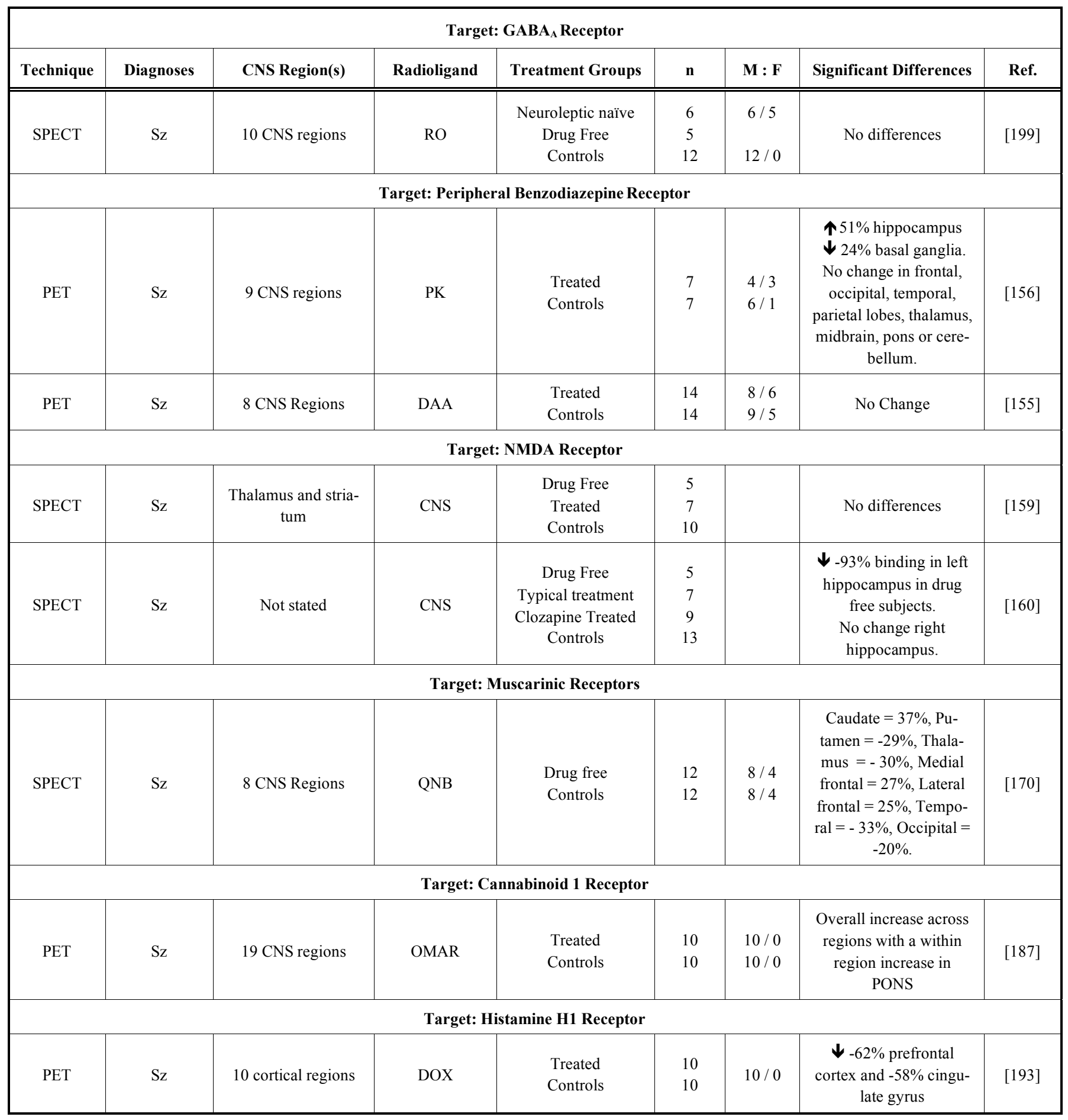

Abbreviations: ALTA $=\left[{ }^{18} \mathrm{~F}\right]$ altanserin $, \mathrm{CNS}=\left[{ }^{123} \mathrm{I}\right] \mathrm{CNS} 1261, \mathrm{DAA}=\left[{ }^{11} \mathrm{C}\right] \mathrm{DAA} 1106, \mathrm{DOX}=\left[{ }^{11} \mathrm{C}\right]$ doxepin, IOM $=[123 \mathrm{I}]$ iomazenil, NMS $=\left[{ }^{11} \mathrm{C}\right]$ methylspiperone, OMAR $=$ $\left[{ }^{11} \mathrm{C}\right] \mathrm{OMAR}, \mathrm{PK}=\left[{ }^{11} \mathrm{C}\right]-(\mathrm{R})-\mathrm{PK} 11195, \mathrm{QNB}=\left[{ }^{123} \mathrm{I}\right] \mathrm{IQNB}, \mathrm{RO}=[11 \mathrm{C}] \mathrm{Ro} 15-4513, \mathrm{SEPTO}=\left[{ }^{18} \mathrm{SF}\right]$ setoperone, Sz $=$ Schizophrenia, SzAff $=$ schizoaffective disorder, WAY $=$ $\left[{ }^{11} \mathrm{C}\right]$ WAY 100635

with schizophrenia [135-137] whilst one study has reported a $19 \%$ decrease in the 5 HT1AR in the amygdala but not seven other CNS regions from subjects with the disorder [138]. These findings are therefore in general agreement with studies using postmortem CNS that have failed to show changes in 5HT1AR in the cortex of subjects with schizophrenia $[139,140]$ rather than the majority of studies which report increased levels of those receptors in subjects with the disor- der [119, 141-144]. At this point it is unclear as to why, in the case of the 5HT1AR, there are discrepancies in findings between postmortem studies and neuroimaging. This is particularly the case given antipsychotic treatment in rats does not appear to affect levels of that receptor [119].

In addition to studies on serotonin receptors, there has been a limited number of studies using neuroimaging that 


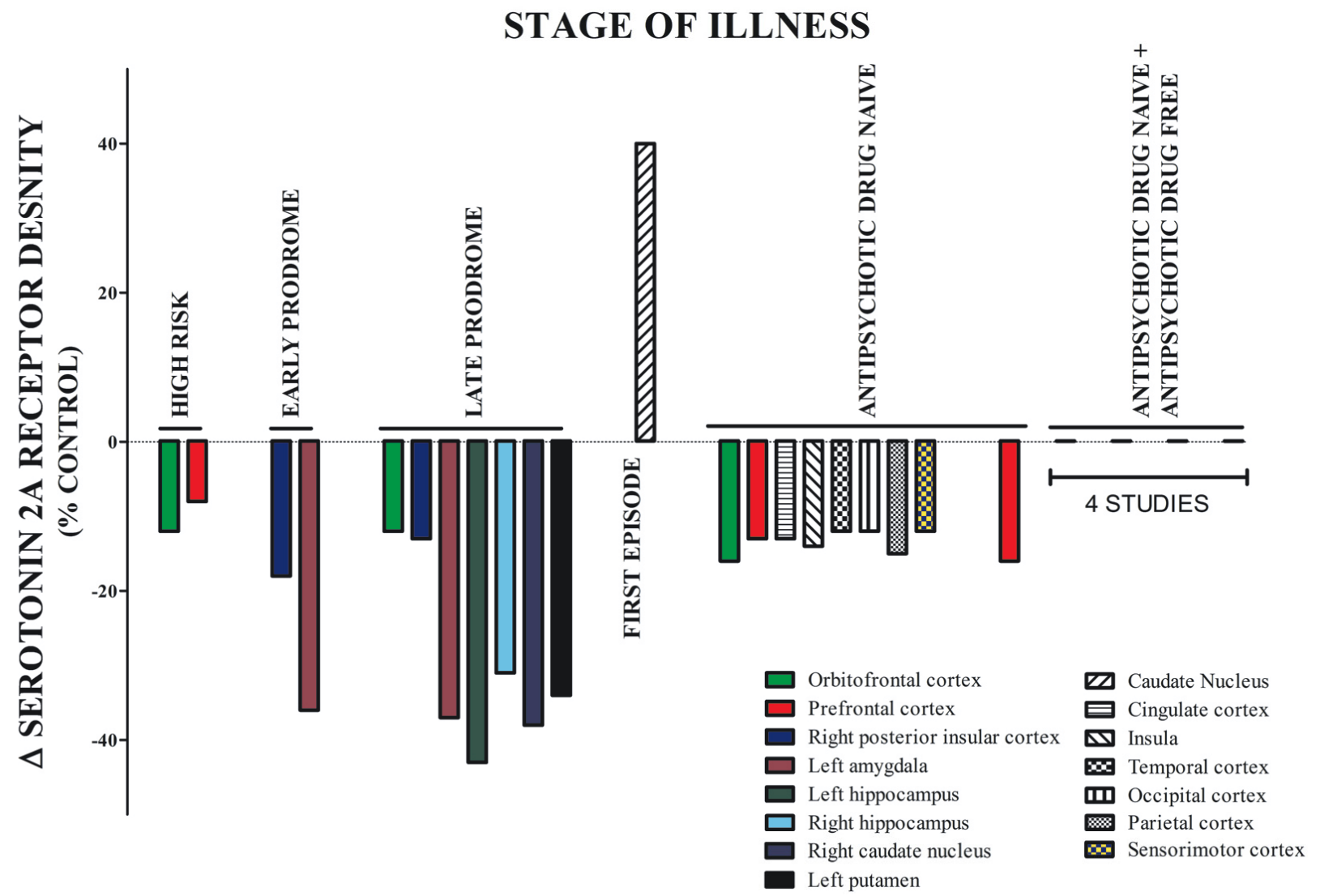

Fig. (1). Region-specific changes in levels of ligand binding to the serotonin $2 \mathrm{~A}$ receptor as measured in neuroimaging studies in people at high-risk of developing schizophrenia or in the prodromal phase, first episode or established phase of the disorder. Individuals with frank schizophrenia are in drug naïve or drug free states during CNS neuroimaging.

suggest levels of the serotonin transporter are not altered in the CNS of subjects with schizophrenia $[66,145]$ which is in line with postmortem studies [146].

\section{NEUROIMAGING STUDIES ON OTHER NEURO- TRANSMITTER SYSTEMS IN SCHIZOPHRENIA}

There have been few other neuroimaging studies on other neurotransmitter systems in the CNS of subjects with schizophrenia. A number of studies have reported there is no change in levels of the benzodiazepine binding site on the $\mathrm{GABA}_{\mathrm{A}}$ receptor in the CNS of subjects with the disorder [147-149]. These findings agree with the majority of findings on that binding site in postmortem tissue from subjects with the schizophrenia [150-154]. One neuroimaging study has shown that the peripheral benzodiazepine receptor is unchanged in $8 \mathrm{CNS}$ regions from drug treated people with schizophrenia [155] which compares to a second study that reported levels of the receptor to be increased $(51 \%)$ in the hippocampus, decreased in the basal ganglia $(-24 \%)$ but unaltered in 7 other CNS regions from a cohort of treated people with the disorder [156]. These data are different to a postmortem study that found decreased levels of peripheral benzodiazepine receptor in the superior parietal cortex, primary visual area and putamen from people with schizophrenia [157]. Thus, further studies on the peripheral benzodiazepine receptor in schizophrenia are required to understand what may be occurring with this binding site, which is predominantly present on astrocytes and microglia and may be a marker of inflammatory activity [158].
Neuroimaging studies of glutamatergic markers have focused on the NMDA receptor with one study reporting no change in $\left[{ }^{123} \mathrm{I}\right] \mathrm{CNS} 1261$ binding to that receptor in the thalamus and striatum from people with schizophrenia [159] . Subsequently, the same group has reported a decrease in levels of the NMDA receptor in the left, but not right, hippocampus from people with the disorder [160]. Significantly, a number of postmortem studies have failed to show any changes in NMDA receptors in the hippocampus [161-164] and striatum $[165,166]$ from people with schizophrenia. In the thalamus, levels NMDA receptors have been reported as increased [167], unchanged [168] or lower [169] in tissue from people with the disorder. Hence, there is a clear need for more studies to try and harmonize data on possible changes in the NMDA receptor in schizophrenia.

One study has reported widespread decreases in $\left[{ }^{123} \mathrm{I}\right]$ iodoquinuclidinyl benzilate ([123I]IQNB) to muscarinic receptors in the CNS from drug free people with schizophrenia [170]. Significantly, there are now many postmortem studies suggesting muscarinic receptors are decreased in the cortex of people with schizophrenia [171-183]. Moreover, a recent study has confirmed the widespread decreases in muscarinic receptors reported in the neuroimaging study using postmortem CNS [183]. In addition, postmortem studies suggest it is the muscarinic M1 receptor that is altered in the cortex of people with schizophrenia $[175,184]$ whereas it is possible that other muscarinic receptors are altered in the hippocampus [179], striatum [185] and thalamus [186] of people with the disorder. 
One study has also measured [11C] OMAR binding to the CB1 receptor and has reported an all of CNS increase in ligand binding with a significant within region increase $(23 \%)$ in binding detected in the Pons [187]. These data tend to support previous postmortem studies that have suggested levels of CB1 receptors are increased in the CNS of subjects with schizophrenia $[188,189]$ rather than those suggesting the levels of that receptor are unchanged [190] or decreased [191] in the CNS of people with the disorder. Further study of the CB1 receptor in the CNS of subjects with schizophrenia would therefore be worthwhile as they may give a better understanding as to why cannabis use may precipitate or worsen the symptoms of the disorder [192].

Finally, one neuroimaging study has reported marked decreases in $\left[{ }^{11} \mathrm{C}\right]$ doxepin binding to the histamine $\mathrm{H} 1$ receptor in the frontal and prefrontal $(-62 \%)$ cortices and the cingulate gyrus $(-58 \%)$ in people with schizophrenia [193]. These data partially support a postmortem finding of decreases in the same receptor in the prefrontal cortex from people with the disorder [194].

\section{CONCLUDING REMARKS}

Findings from molecular neuroimaging studies are now clearly impacting on our understanding of the neurochemistry of schizophrenia. As with other methodologies, such studies have methodological confounds which include limitations on the number of available ligands limiting the number of molecules that can be studied, limitations on the number of scans per individual because of cumulative radioactive load and the practical aspects of the methodologies limiting diagnostic cohort sizes. The latter issue is of growing significance with the increasing acknowledgement that schizophrenia is a syndrome and that not being able to dissect the syndrome into individual diagnostically homogenous groups is limiting the progression of our understanding of the causes of the schizophrenias [195]. On the other hand, neuroimaging could be a front line tool in measuring CNS biomarkers that allow the separation of schizophrenia into sub-groups, such as the sub-group that has a marked loss of cortical muscarinic receptors [181]. Therefore the ongoing development of ligands to be used with molecular imaging technology is critical, as is the capacity to increase the cohort sizes studied.

At a pragmatic level, neuroimaging studies of some markers in the CNS of subjects with people with schizophrenia are confirming findings from studies using postmortem CNS but in drug naïve and drug free people. Such findings decrease concerns that such postmortem studies are reflecting some postmortem artifact or a simple drug effect. However, neuroimaging studies are producing exciting novel findings in their own right. Thus, molecular imaging has revealed abnormalities in the synthesis and release of dopamine in the CNS from subjects with schizophrenia; an effect that may be compounded by a failure to appropriately downregulate DADR2 in the caudate nucleus. In addition, data suggests that decreased levels of 5HT2AR occur early in the progression towards schizophrenia raising the intriguing possibility that decreased 5HT2AR may be a marker for those at risk or in the prodromal phase that are likely to progress to frank illness. Such findings cannot be made using any other technology yet available and contribute a significant increase in our knowledge on the pathophysiology of schizophrenia.

\section{CONFLICT OF INTEREST}

The author(s) confirm that this article content has no conflicts of interest.

\section{ACKNOWLEDGEMENTS}

The author is an NHMRC Senior Research Fellow (APP1002240) who receives funding from the Victorian Government's Operational Infrastructure Support Program and the Rebecca L. Cooper Medical Research Foundation.

\section{REFERENCES}

[1] Frost, J. J. Molecular imaging of the brain: a historical perspective. Neuroimaging Clin.N.Am., 2003, 13, 653-658.

[2] Agid, O.; Shapira, B.; Zislin, J.; Ritsner, M.; Hanin, B.; Murad, H.; Troudart, T.; Bloch, M.; Heresco-Levy, U.; Lerer, B. Environment and vulnerability to major psychiatric illness: a case control study of early parental loss in major depression, bipolar disorder and schizophrenia. Mol Psychiatry, 1999, 4, 163-172.

[3] Tsuang, M. Schizophrenia: genes and environment. Biological Psychiatry, 2000, 47, 210-220.

[4] Crow, T. J. Schizophrenia as the price that homo sapiens pays for language: a resolution of the central paradox in the origin of the species. Brain Res.Brain Res.Rev., 2000, 31, 118-129.

[5] Dean, B. Is schizophrenia the price of human central nervous system complexity? Aust.N.Z.J.Psychiatry, 2009, 43, 13-24.

[6] Harrison, P. J. Schizophrenia: a disorder of neurodevelopment? Curr.Opin.Neurobiol., 1997, 7, 285-289.

[7] Meltzer, H. Y. Biological studies in schizophrenia. Schizophr.Bull., 1987, 13, 77-111.

[8] Dean, B. Signal transmission, rather than reception, is the underlying neurochemical abnormality in schizophrenia. Aust.N.Z.J.Psychiatry, 2000, 34, 560-569.

[9] Dean, B. The neurobiology of bipolar disorder: findings using human postmortem central nervous system tissue. Aust.N.Z.J.Psychiatry, 2004, 38, 135-140.

[10] Carlsson, A. Does dopamine play a role in schizophrenia? Psychol.Med., 1977, 7, 583-597.

[11] Sibley, D. R.; Monsma, F. J., Jr. Molecular biology of dopamine receptors. Trends Pharmacol.Sci., 1992, 13, 61-69.

[12] Seeman, P.; Lee, T. Antipsychotic drugs: direct correlation between clinical potency and presynaptic action on dopamine neurons Science, 1975, 188, 1217-1219.

[13] Wong, D. F.; Wagner, H. N., Jr.; Tune, L. E.; Dannals, R. F.; Pearlson, G. D.; Links, J. M.; Tamminga, C. A.; Broussolle, E. P.; Ravert, H. T.; Wilson, A. A.; Toung, J. K.; Malat, J.; Williams, J. A.; O'Tuama, L. A.; Snyder, S. H.; Kuhar, M. J.; Gjedde, A. Positron emission tomography reveals elevated D2 dopamine receptors in drug-naive schizophrenics. Science, 1986, 234, 15581563.

[14] Farde, L.; Wiesel, F. A.; Hall, H.; Halldin, C.; Stone-Elander, S.; Sedvall, G. No D2 receptor increase in PET study of schizophrenia. Arch.Gen.Psychiatry, 1987, 44, 671-672.

[15] Martinot, J. L.; Huret, J. D.; Peron-Magnan, P.; Mazoyer, B. M.; Baron, J. C.; Caillard, V.; Syrota, A.; Loo, H. Striatal D2 dopaminergic receptor status ascertained in vivo by positron emission tomography and $76 \mathrm{Br}$-bromospiperone in untreated schizophrenics. Psychiatry Research, 1989, 29, 357-358.

[16] Tune, L. E.; Wong, D. F.; Pearlson, G.; Strauss, M.; Young, T.; Shaya, E. K.; Dannals, R. F.; Wilson, A. A.; Ravert, H. T.; Sapp, J.; Dopamine D2 receptor density estimates in schizophrenia: a positron emission tomography study with $11 \mathrm{C}-\mathrm{N}$-methylspiperone. Psychiatry Research, 1993, 49, 219-237.

[17] Tune, L.; Barta, P.; Wong, D.; Powers, R. E.; Pearlson, G.; Tien, A. Y.; Wagner, H. N. Striatal dopamine D2 receptor quantification and superior temporal gyrus: volume determination in 14 chronic schizophrenic subjects. Psychiatry Research, 1996, 67, 155-158.

[18] Pearlson, G. D.; Wong, D. F.; Tune, L. E.; Ross, C. A.; Chase, G. A.; Links, J. M.; Dannals, R. F.; Wilson, A. A.; Ravert, H. T.; Wagner, H. N., Jr.; . In vivo D2 dopamine receptor density in psychotic and nonpsychotic patients with bipolar disorder. Arch.Gen.Psychiatry, 1995, 52, 471-477. 
[19] Wong, D. F.; Pearlson, G. D.; Tune, L. E.; Young, L. T.; Meltzer, C. C.; Dannals, R. F.; Ravert, H. T.; Reith, J.; Kuhar, M. J.; Gjedde, A. Quantification of neuroreceptors in the living human brain: IV. Effect of aging and elevations of D2-like receptors in schizophrenia and bipolar illness. J.Cereb.Blood Flow Metab, 1997, 17, 331-342.

[20] Pearlson, G. D.; Tune, L. E.; Wong, D. F.; Aylward, E. H.; Barta, P. E.; Powers, R. E.; Tien, A. Y.; Chase, G. A.; Harris, G. J.; Rabins, P. V. Quantitative D2 dopamine receptor PET and structural MRI changes in late-onset schizophrenia. Schizophr.Bull., 1993, 19, 783-795.

[21] Hietala, J.; Syvalahti, E.; Vuorio, K.; Nagren, K.; Lehikoinen, P.; Ruotsalainen, U.; Rakkolainen, V.; Lehtinen, V.; Wegelius, U. Striatal D2 dopamine receptor characteristics in neuroleptic-naive schizophrenic patients studied with positron emission tomography. Arch.Gen.Psychiatry, 1994, 51, 116-123.

[22] Nordstrom, A. L.; Farde, L.; Eriksson, L.; Halldin, C. No elevated D2 dopamine receptors in neuroleptic-naive schizophrenic patients revealed by positron emission tomography and [11C]Nmethylspiperone. Psychiatry Research, 1995, 61, 67-83.

[23] Farde, L.; Wiesel, F. A.; Stone-Elander, S.; Halldin, C.; Nordstrom, A. L.; Hall, H.; Sedvall, G. D2 dopamine receptors in neurolepticnaive schizophrenic patients. A positron emission tomography study with [11C]raclopride. Arch.Gen.Psychiatry, 1990, 47, 213219.

[24] Talvik, M.; Nordstrom, A. L.; Olsson, H.; Halldin, C.; Farde, L. Decreased thalamic D2/D3 receptor binding in drug-naive patients with schizophrenia: a PET study with [11C]FLB 457. Int.J.Neuropsychopharmacol., 2003, 6, 361-370.

[25] Martinot, J. L.; Paillere-Martinot, M. L.; Loc'h, C.; Hardy, P.; Poirier, M. F.; Mazoyer, B.; Beaufils, B.; Maziere, B.; Allilaire, J. F.; Syrota, A. The estimated density of D2 striatal receptors in schizophrenia. A study with positron emission tomography and 76Br-bromolisuride. Br.J.Psychiatry, 1991, 158, 346-350.

[26] Pilowsky, L. S.; Costa, D. C.; Ell, P. J.; Verhoeff, N. P.; Murray, R. M.; Kerwin, R. W. D2 dopamine receptor binding in the basal ganglia of antipsychotic-free schizophrenic patients. An 123IIBZM single photon emission computerised tomography study. Br.J.Psychiatry, 1994, 164, 16-26.

[27] Knable, M. B.; Egan, M. F.; Heinz, A.; Gorey, J.; Lee, K. S.; Coppola, R.; Weinberger, D. R. Altered dopaminergic function and negative symptoms in drug-free patients with schizophrenia. [123I]-iodobenzamide SPECT study. Br.J.Psychiatry, 1997, 171, 574-577.

[28] Schroder, J.; Bubeck, B.; Silvestri, S.; Demisch, S.; Sauer, H. Gender differences in D2 dopamine receptor binding in drug-naive patients with schizophrenia: an [123I]iodobenzamide single photon emission computed tomography study. Psychiatry Research, 1997, $75,115-123$.

[29] Lomena, F.; Catafau, A. M.; Parellada, E.; Bernardo, M.; Font, M.; Gutierrez, F.; Pavia, J. Striatal dopamine D2 receptor density in neuroleptic-naive and in neuroleptic-free schizophrenic patients: an 123I-IBZM-SPECT study. Psychophamacology (Berlin), 2004, $172,165-169$.

[30] Parellada, E.; Lomena, F.; Catafau, A. M.; Bernardo, M.; Font, M.; Fernandez-Egea, E.; Pavia, J.; Gutierrez, F. Lack of sex differences in striatal dopamine D2 receptor binding in drug-naive schizophrenic patients: an IBZM-SPECT study. Psychiatry Research, 2004, 130, 79-84.

[31] Bloemen, O. J.; de Koning, M. B.; Gleich, T.; Meijer, J.; de, H. L.; Linszen, D. H.; Booij, J.; van Amelsvoort, T. A. Striatal dopamine $\mathrm{D}(2 / 3)$ receptor binding following dopamine depletion in subjects at Ultra High Risk for psychosis. European Neuropsychopharmacology, 2012,

[32] Seeman, P.; Niznik, H. B. Dopamine receptors and transporters in Parkinson's disease and schizophrenia. FASEB J., 1990, 4, 27372744.

[33] Hess, E. J.; Bracha, H. S.; Kleinman, J. E.; Creese, I. Dopamine receptor subtype imbalance in schizophrenia. Life Sci., 1987, 40, 1487-1497.

[34] Dean, B.; Pavey, G.; Opeskin, K. [3H]raclopride binding to brain tissue from subjects with schizophrenia: methodological aspects. Neuropharmacology, 1997, 36, 779-786.

[35] Knable, M. B.; Hyde, T. M.; Herman, M. M.; Carter, J. M.; Bigelow, L.; Kleinman, J. E. Quantitative autoradiography of dopamine-D1 receptors, D2 receptors, and dopamine uptake sites in postmortem striatal specimens from schizophrenic patients. Biological Psychiatry, 1994, 36, 827-835.

[36] Suhara, T.; Okubo, Y.; Yasuno, F.; Sudo, Y.; Inoue, M.; Ichimiya, T.; Nakashima, Y.; Nakayama, K.; Tanada, S.; Suzuki, K.; Halldin, C.; Farde, L. Decreased dopamine D2 receptor binding in the anterior cingulate cortex in schizophrenia. Arch.Gen.Psychiatry, 2002, 59, 25-30.

[37] Tuppurainen, H.; Kuikka, J.; Viinamaki, H.; Husso-Saastamoinen, M.; Bergstrom, K.; Tiihonen, J. Extrastriatal dopamine D 2/3 receptor density and distribution in drug-naive schizophrenic patients. Mol.Psychiatry, 2003, 8, 453-455.

[38] Meador-Woodruff, J. H.; Haroutunian, V.; Powchik, P.; Davidson, M.; Davis, K. L.; Watson, S. J. Dopamine receptor transcript expression in striatum and prefrontal and occipital cortex. Focal abnormalities in orbitofrontal cortex in schizophrenia. Arch.Gen.Psychiatry, 1997, 54, 1089-1095.

[39] Zavitsanou, K.; Huang, X. F. Decreased [(3)H]spiperone binding in the anterior cingulate cortex of schizophrenia patients: an autoradiographic study. Neuroscience, 2002, 109, 709-716.

[40] Dean, B.; Hussain, T.; Hayes, W.; Scarr, E.; Kitsoulis, S.; Hill, C.; Opeskin, K.; Copolov, D. L. Changes in serotonin2A and GABA(A) receptors in schizophrenia: studies on the human dorsolateral prefrontal cortex. J.Neurochem., 1999, 72, 1593-1599.

[41] Buchsbaum, M. S.; Christian, B. T.; Lehrer, D. S.; Narayanan, T. K.; Shi, B.; Mantil, J.; Kemether, E.; Oakes, T. R.; Mukherjee, J. D2/D3 dopamine receptor binding with [F-18]fallypride in thalamus and cortex of patients with schizophrenia. Schizophr.Res., 2006, 85, 232-244.

[42] Talvik, M.; Nordstrom, A. L.; Okubo, Y.; Olsson, H.; Borg, J.; Halldin, C.; Farde, L. Dopamine D2 receptor binding in drug-naive patients with schizophrenia examined with raclopride-C11 and positron emission tomography. Psychiatry Research, 2006, 148, 165-173.

[43] Rinne, J. O.; Hietala, J.; Ruotsalainen, U.; Sako, E.; Laihinen, A.; Nagren, K.; Lehikoinen, P.; Oikonen, V.; Syvalahti, E. Decrease in human striatal dopamine D2 receptor density with age: a PET study with [11C]raclopride. J.Cereb.Blood Flow Metab, 1993, 13, 310314 .

[44] Kaasinen, V.; Vilkman, H.; Hietala, J.; Nagren, K.; Helenius, H. Olsson, H.; Farde, L.; Rinne, J. Age-related dopamine D2/D3 receptor loss in extrastriatal regions of the human brain. Neurobiol.Aging, 2000, 21, 683-688.

[45] Seeman, P.; Bzowej, N. H.; Guan, H. C.; Bergeron, C.; Becker, L. E.; Reynolds, G. P.; Bird, E. D.; Riederer, P.; Jellinger, K.; Watanabe, S.; . Human brain dopamine receptors in children and aging adults. Synapse, 1987, 1, 399-404.

[46] Dean, B.; Keriakous, D.; Scarr, E.; Thomas, E. A. Gene expression profiling in Brodmann's area 46 from subjects with schizophrenia. Aust.N.Z.J.Psychiatry, 2007, 41, 308-320.

[47] Narayan, S.; Tang, B.; Head, S. R.; Gilmartin, T. J.; Sutcliffe, J. G.; Dean, B.; Thomas, E. A. Molecular profiles of schizophrenia in the CNS at different stages of illness. Brain Res., 2008, 1239, 235-248.

[48] Tang, B.; Chang, W. L.; Lanigan, C. M.; Dean, B.; Sutcliffe, J. G.; Thomas, E. A. Normal human aging and early-stage schizophrenia share common molecular profiles. Aging Cell, 2009, 8, 339-342.

[49] Kebabian, J. W.; Calne, D. B. Multiple receptors for dopamine. Nature, 1979, 277, 93-96.

[50] Hall, H.; Sedvall, G.; Magnusson, O.; Kopp, J.; Halldin, C.; Farde, L. Distribution of D1- and D2-dopamine receptors, and dopamine and its metabolites in the human brain. Neuropsychopharmacology, 1994, 11, 245-256.

[51] Okubo, Y.; Suhara, T.; Suzuki, K.; Kobayashi, K.; Inoue, O.; Terasaki, O.; Someya, Y.; Sassa, T.; Sudo, Y.; Matsushima, E.; Iyo, M.; Tateno, Y.; Toru, M. Decreased prefrontal dopamine D1 receptors in schizophrenia revealed by PET. Nature, 1997, 385 , 634-636.

[52] Kosaka, J.; Takahashi, H.; Ito, H.; Takano, A.; Fujimura, Y.; Matsumoto, R.; Nozaki, S.; Yasuno, F.; Okubo, Y.; Kishimoto, T.; Suhara, T. Decreased binding of [11C]NNC112 and [11C]SCH23390 in patients with chronic schizophrenia. Life Sci., 2010, $86,814-818$.

[53] Abi-Dargham, A.; Xu, X.; Thompson, J. L.; Gil, R.; Kegeles, L. S.; Urban, N. B.; Narendran, R.; Hwang, D. R.; Laruelle, M.; Slifstein, M. Increased prefrontal cortical D1 receptors in drug naive patients with schizophrenia: a PET study with [11C]NNC112. J.Psychopharmacol., 2011, 
[54] Abi-Dargham, A.; Mawlawi, O.; Lombardo, I.; Gil, R.; Martinez, D.; Huang, Y.; Hwang, D. R.; Keilp, J.; Kochan, L.; Van Heertum, R.; Gorman, J. M.; Laruelle, M. Prefrontal dopamine D1 receptors and working memory in schizophrenia. J.Neurosci., 2002, 22, 3708-3719.

[55] Karlsson, P.; Farde, L.; Halldin, C.; Sedvall, G. PET study of D(1) dopamine receptor binding in neuroleptic-naive patients with schizophrenia. Am.J.Psychiatry, 2002, 159, 761-767.

[56] Pimoule, C.; Schoemaker, H.; Reynolds, G. P.; Langer, S. Z. $[3 \mathrm{H}] \mathrm{SCH} 23390$ labeled D1 dopamine receptors are unchanged in schizophrenia and Parkinson's disease. Eur.J.Pharmacol., 1985, 114, 235-237.

[57] Seeman, P.; Bzowej, N. H.; Guan, H. C.; Bergeron, C.; Reynolds, G. P.; Bird, E. D.; Riederer, P.; Jellinger, K.; Tourtellotte, W. W. Human brain D1 and D2 dopamine receptors in schizophrenia, Alzheimer's, Parkinson's, and Huntington's diseases. Neuropsychopharmacology, 1987, 1, 5-15.

[58] Knable, M. B.; Hyde, T. M.; Murray, A. M.; Herman, M. M.; Kleinman, J. E. A postmortem study of frontal cortical dopamine D1 receptors in schizophrenics, psychiatric controls, and normal controls. Biological Psychiatry, 1996, 40, 1191-1199.

[59] Domyo, T.; Kurumaji, A.; Toru, M. An increase in [3H]SCH23390 binding in the cerebral cortex of postmortem brains of chronic schizophrenics. J.Neural Transm., 2001, 108, 1475-1484.

[60] Buckland, P. R.; O'Donovan, M. C.; McGuffin, P. Changes in dopamine D1, D2 and D3 receptor mRNA levels in rat brain following antipsychotic treatment. Psychophamacology (Berlin), 1992, 106, 479-483.

[61] D'Souza, U.; McGuffin, P.; Buckland, P. R. Antipsychotic regulation of dopamine D1, D2 and D3 receptor mRNA. Neuropharmacology, 1997, 36, 1689-1696.

[62] Lidow, M. S.; Elsworth, J. D.; Goldman-Rakic, P. S. Downregulation of the D1 and D5 dopamine receptors in the primate prefrontal cortex by chronic treatment with antipsychotic drugs. J.Pharmacol.Exp.Ther., 1997, 281, 597-603.

[63] Dean, B.; Hussain, T.; Scarr, E.; Pavey, G.; Copolov, D. L. Extended treatment with typical and atypical antipsychotic drugs differential effects on the densities of dopamine D2-like and GABAA receptors in rat striatum. Life Sci., 2001, 69, 1257-1268.

[64] Giros, B.; Jaber, M.; Jones, S. R.; Wightman, R. M.; Caron, M. G. Hyperlocomotion and indifference to cocaine and amphetamine in mice lacking the dopamine transporter. Nature, 1996, 379, 606612.

[65] Laakso, A.; Vilkman, H.; Alakare, B.; Haaparanta, M.; Bergman, J.; Solin, O.; Peurasaari, J.; Rakkolainen, V.; Syvalahti, E.; Hietala, J. Striatal dopamine transporter binding in neuroleptic-naive patients with schizophrenia studied with positron emission tomography. Am.J.Psychiatry, 2000, 157, 269-271

[66] Laruelle, M.; Abi-Dargham, A.; van Dyck, C.; Gil, R.; D'Souza, D. C.; Krystal, J.; Seibyl, J.; Baldwin, R.; Innis, R. Dopamine and serotonin transporters in patients with schizophrenia: an imaging study with [(123)I]beta-CIT. Biological Psychiatry, 2000, 47, 371379.

[67] Hsiao, M. C.; Lin, K. J.; Liu, C. Y.; Tzen, K. Y.; Yen, T. C. Dopamine transporter change in drug-naive schizophrenia: an imaging study with 99mTc-TRODAT-1. Schizophr.Res., 2003, 65, 39-46.

[68] Yang, Y. K.; Yu, L.; Yeh, T. L.; Chiu, N. T.; Chen, P. S.; Lee, I. H. Associated alterations of striatal dopamine D2/D3 receptor and transporter binding in drug-naive patients with schizophrenia: a dual-isotope SPECT study. Am.J.Psychiatry, 2004, 161, 14961498.

[69] Schmitt, G. J.; Meisenzahl, E. M.; Frodl, T.; La, F. C.; Hahn, K.; Moller, H. J.; Dresel, S. The striatal dopamine transporter in firstepisode, drug-naive schizophrenic patients: evaluation by the new SPECT-ligand[99mTc]TRODAT-1. J.Psychopharmacol., 2005, 19, 488-493.

[70] Schmitt, G. J.; Frodl, T.; Dresel, S.; La, F. C.; Bottlender, R.; Koutsouleris, N.; Hahn, K.; Moller, H. J.; Meisenzahl, E. M. Striatal dopamine transporter availability is associated with the productive psychotic state in first episode, drug-naive schizophrenic patients. Eur.Arch.Psychiatry Clin.Neurosci., 2006, $256,115-121$

[71] Schmitt, G. J.; La, F. C.; Dresel, S.; Frodl, T.; Hahn, K.; Moller, H. J.; Meisenzahl, E. M. Dual-isotope SPECT imaging of striatal dopamine: first episode, drug naive schizophrenic patients. Schizophr.Res., 2008, 101, 133-141.

[72] Arakawa, R.; Ichimiya, T.; Ito, H.; Takano, A.; Okumura, M.; Takahashi, H.; Takano, H.; Yasuno, F.; Kato, M.; Okubo, Y.; Suhara, T. Increase in thalamic binding of [(11)C]PE2I in patients with schizophrenia: a positron emission tomography study of dopamine transporter. J.Psychiatr.Res., 2009, 43, 1219-1223.

[73] Laakso, A.; Bergman, J.; Haaparanta, M.; Vilkman, H.; Solin, O.; Syvalahti, E.; Hietala, J. Decreased striatal dopamine transporter binding in vivo in chronic schizophrenia. Schizophr.Res., 2001, 52, 115-120.

[74] Mateos, J. J.; Lomena, F.; Parellada, E.; Font, M.; Fernandez, E.; Pavia, J.; Prats, A.; Pons, F.; Bernardo, M. Decreased striatal dopamine transporter binding assessed with [123I] FP-CIT in firstepisode schizophrenic patients with and without short-term antipsychotic-induced parkinsonism. Psychophamacology (Berlin), 2005, 181, 401-406.

[75] Mateos, J. J.; Lomena, F.; Parellada, E.; Mireia, F.; FernandezEgea, E.; Pavia, J.; Prats, A.; Pons, F.; Bernardo, M. Lower striatal dopamine transporter binding in neuroleptic-naive schizophrenic patients is not related to antipsychotic treatment but it suggests an illness trait. Psychophamacology (Berlin), 2007, 191, 805-811.

[76] Sjoholm, H.; Bratlid, T.; Sundsfjord, J. 123I-beta-CIT SPECT demonstrates increased presynaptic dopamine transporter binding sites in basal ganglia in vivo in schizophrenia. Psychophamacology (Berlin), 2004, 173, 27-31.

[77] Pearce, R. K.; Seeman, P.; Jellinger, K.; Tourtellotte, W. W. Dopamine uptake sites and dopamine receptors in Parkinson's disease and schizophrenia. Eur.Neurol., 1990, 30 Suppl 1, 9-14.

[78] Hitri, A.; Casanova, M. F.; Kleinman, J. E.; Weinberger, D. R.; Wyatt, R. J. Age-related changes in [3H]GBR 12935 binding site density in the prefrontal cortex of controls and schizophrenics. Biological Psychiatry, 1995, 37, 175-182.

[79] Dean, B.; Hussain, T. Studies on dopaminergic and GABAergic markers in striatum reveals a decrease in the dopamine transporter in schizophrenia. Schizophr.Res., 2001, 52, 107-114.

[80] Tarazi, F. I.; Zhang, K.; Baldessarini, R. J. Olanzapine, quetiapine, and risperidone: long-term effects on monoamine transporters in rat forebrain. Neurosci.Lett., 2000, 287, 81-84.

[81] Hietala, J.; Syvalahti, E.; Vuorio, K.; Rakkolainen, V.; Bergman, J.; Haaparanta, M.; Solin, O.; Kuoppamaki, M.; Kirvela, O.; Ruotsalainen, U.; . Presynaptic dopamine function in striatum of neuroleptic-naive schizophrenic patients. Lancet, 1995, 346, 11301131

[82] Laruelle, M.; Abi-Dargham, A.; van Dyck, C. H.; Gil, R.; D'Souza, C. D.; Erdos, J.; McCance, E.; Rosenblatt, W.; Fingado, C.; Zoghbi, S. S.; Baldwin, R. M.; Seibyl, J. P.; Krystal, J. H.; Charney, D. S.; Innis, R. B. Single photon emission computerized tomography imaging of amphetamine-induced dopamine release in drug-free schizophrenic subjects. Proc.Natl.Acad.Sci.U.S.A, 1996, 93, 9235-9240

[83] Hietala, J.; Syvalahti, E.; Vilkman, H.; Vuorio, K.; Rakkolainen, V.; Bergman, J.; Haaparanta, M.; Solin, O.; Kuoppamaki, M.; Eronen, E.; Ruotsalainen, U.; Salokangas, R. K. Depressive symptoms and presynaptic dopamine function in neuroleptic-naive schizophrenia. Schizophr.Res., 1999, 35, 41-50.

[84] Elkashef, A. M.; Doudet, D.; Bryant, T.; Cohen, R. M.; Li, S. H.; Wyatt, R. J. 6-(18)F-DOPA PET study in patients with schizophrenia. Positron emission tomography. Psychiatry Research, 2000, 100, 1-11.

[85] Kumakura, Y.; Cumming, P.; Vernaleken, I.; Buchholz, H. G.; Siessmeier, T.; Heinz, A.; Kienast, T.; Bartenstein, P.; Grunder, G. Elevated $[18 \mathrm{~F}]$ fluorodopamine turnover in brain of patients with schizophrenia: an [18F]fluorodopa/positron emission tomography study. J.Neurosci., 2007, 27, 8080-8087.

[86] Bose, S. K.; Turkheimer, F. E.; Howes, O. D.; Mehta, M. A Cunliffe, R.; Stokes, P. R.; Grasby, P. M. Classification of schizophrenic patients and healthy controls using [18F] fluorodopa PET imaging. Schizophr.Res., 2008, 106, 148-155.

[87] Abi-Dargham, A.; van de Giessen, E.; Slifstein, M.; Kegeles, L. S.; Laruelle, M. Baseline and amphetamine-stimulated dopamine activity are related in drug-naive schizophrenic subjects. Biological Psychiatry, 2009, 65, 1091-1093.

[88] Abi-Dargham, A.; Gil, R.; Krystal, J.; Baldwin, R. M.; Seibyl, J. P.; Bowers, M.; van Dyck, C. H.; Charney, D. S.; Innis, R. B.; Laruelle, M. Increased striatal dopamine transmission in 
schizophrenia: confirmation in a second cohort. Am.J.Psychiatry, 1998, 155, 761-767.

[89] Breier, A.; Su, T. P.; Saunders, R.; Carson, R. E.; Kolachana, B. S.; de Bartolomeis, A.; Weinberger, D. R.; Weisenfeld, N.; Malhotra, A. K.; Eckelman, W. C.; Pickar, D. Schizophrenia is associated with elevated amphetamine-induced synaptic dopamine concentrations: evidence from a novel positron emission tomography method. Proc.Natl.Acad.Sci.U.S.A, 1997, 94, 25692574.

[90] Abi-Dargham, A.; Kegeles, L. S.; Zea-Ponce, Y.; Mawlawi, O.; Martinez, D.; Mitropoulou, V.; O'Flynn, K.; Koenigsberg, H. W.; Van, H. R.; Cooper, T.; Laruelle, M.; Siever, L. J. Striatal amphetamine-induced dopamine release in patients with schizotypal personality disorder studied with single photon emission computed tomography and [123I]iodobenzamide. Biological Psychiatry, 2004, 55, 1001-1006.

[91] Volkow, N. D.; Chang, L.; Wang, G. J.; Fowler, J. S.; Ding, Y. S.; Sedler, M.; Logan, J.; Franceschi, D.; Gatley, J.; Hitzemann, R.; Gifford, A.; Wong, C.; Pappas, N. Low level of brain dopamine D2 receptors in methamphetamine abusers: association with metabolism in the orbitofrontal cortex. Am.J.Psychiatry, 2001, 158, 2015-2021.

[92] Sekine, Y.; Iyo, M.; Ouchi, Y.; Matsunaga, T.; Tsukada, H.; Okada, H.; Yoshikawa, E.; Futatsubashi, M.; Takei, N.; Mori, N. Methamphetamine-related psychiatric symptoms and reduced brain dopamine transporters studied with PET. Am.J.Psychiatry, 2001, 158, 1206-1214.

[93] Barr, A. M.; Panenka, W. J.; MacEwan, G. W.; Thornton, A. E.; Lang, D. J.; Honer, W. G.; Lecomte, T. The need for speed: an update on methamphetamine addiction. J.Psychiatry Neurosci., 2006, 31, 301-313.

[94] Gibb, W. R.; Lees, A. J. Anatomy, pigmentation, ventral and dorsal subpopulations of the substantia nigra, and differential cell death in Parkinson's disease. J.Neurol.Neurosurg.Psychiatry, 1991, 54, 388396.

[95] Rinne, U. K.; Laihinen, A.; Rinne, J. O.; Nagren, K.; Bergman, J.; Ruotsalainen, U. Positron emission tomography demonstrates dopamine D2 receptor supersensitivity in the striatum of patients with early Parkinson's disease. Mov Disord., 1990, 5, 55-59.

[96] Kaasinen, V.; Ruottinen, H. M.; Nagren, K.; Lehikoinen, P.; Oikonen, V.; Rinne, J. O. Upregulation of putaminal dopamine D2 receptors in early Parkinson's disease: a comparative PET study with $[11 \mathrm{C}]$ raclopride and $[11 \mathrm{C}] \mathrm{N}$-methylspiperone. J.Nucl.Med., 2000, 41, 65-70.

[97] Bartlett, S. E.; Enquist, J.; Hopf, F. W.; Lee, J. H.; Gladher, F.; Kharazia, V.; Waldhoer, M.; Mailliard, W. S.; Armstrong, R.; Bonci, A.; Whistler, J. L. Dopamine responsiveness is regulated by targeted sorting of D2 receptors. Proc.Natl.Acad.Sci.U.S.A, 2005, 102, 11521-11526.

[98] Breier, A. Serotonin, schizophrenia and antipsychotic drug action. Schizophr.Res., 1995, 14, 187-202.

[99] Peroutka, S. J.; Snyder, S. H. Multiple serotonin receptors: differential binding of [3H]5-hydroxytryptamine, [3H]lysergic acid diethylamide and [3H]spiroperidol. Mol Pharmacol., 1979, 16, 687-699.

[100] Baumeister, A. A.; Hawkins, M. F. The serotonin hypothesis of schizophrenia: a historical case study on the heuristic value of theory in clinical neuroscience. J.Hist Neurosci., 2004, 13, 277 291.

[101] Meltzer, H. Y. The importance of serotonin-dopamine interactions in the action of clozapine. Br.J.Psychiatry Suppl, 1992, 22-29.

[102] Dean, B. The cortical serotonin2A receptor and the pathology of schizophrenia: a likely accomplice. J.Neurochem., 2003, 85, 1-13.

[103] Trichard, C.; Paillere-Martinot, M. L.; Attar-Levy, D.; Blin, J.; Feline, A.; Martinot, J. L. No serotonin 5-HT2A receptor density abnormality in the cortex of schizophrenic patients studied with PET. Schizophr.Res., 1998, 31, 13-17.

[104] Lewis, R.; Kapur, S.; Jones, C.; DaSilva, J.; Brown, G. M.; Wilson, A. A.; Houle, S.; Zipursky, R. B. Serotonin 5-HT2 receptors in schizophrenia: a PET study using $[18 \mathrm{~F}]$ setoperone in neurolepticnaive patients and normal subjects. Am.J.Psychiatry, 1999, 156, 7278.

[105] Okubo, Y.; Suhara, T.; Suzuki, K.; Kobayashi, K.; Inoue, O.; Terasaki, O.; Someya, Y.; Sassa, T.; Sudo, Y.; Matsushima, E.; Iyo, M.; Tateno, Y.; Toru, M. Serotonin 5-HT2 receptors in schizophrenic patients studied by positron emission tomography. Life Sci., 2000, 66, 2455-2464.

[106] Verhoeff, N. P.; Meyer, J. H.; Kecojevic, A.; Hussey, D.; Lewis, R.; Tauscher, J.; Zipursky, R. B.; Kapur, S. A voxel-by-voxel analysis of $[18 \mathrm{~F}]$ setoperone PET data shows no substantial serotonin 5-HT(2A) receptor changes in schizophrenia. Psychiatry Research, 2000, 99, 123-135.

[107] Ngan, E. T.; Yatham, L. N.; Ruth, T. J.; Liddle, P. F. Decreased serotonin $2 \mathrm{~A}$ receptor densities in neuroleptic-naive patients with schizophrenia: A PET study using [(18)F]setoperone. Am.J.Psychiatry, 2000, 157, 1016-1018.

[108] Hurlemann, R.; Matusch, A.; Kuhn, K. U.; Berning, J.; Elmenhorst, D.; Winz, O.; Kolsch, H.; Zilles, K.; Wagner, M.; Maier, W. Bauer, A. 5-HT2A receptor density is decreased in the at-risk mental state. Psychophamacology (Berlin), 2008, 195, 579-590.

[109] Hurlemann, R.; Boy, C.; Meyer, P. T.; Scherk, H.; Wagner, M. Herzog, H.; Coenen, H. H.; Vogeley, K.; Falkai, P.; Zilles, K.; Maier, W.; Bauer, A. Decreased prefrontal 5-HT2A receptor binding in subjects at enhanced risk for schizophrenia. Anat.Embryol.(Berl), 2005, 210, 519-523.

[110] Rasmussen, H.; Erritzoe, D.; Andersen, R.; Ebdrup, B. H.; Aggernaes, B.; Oranje, B.; Kalbitzer, J.; Madsen, J.; Pinborg, L. H.; Baare, W.; Svarer, C.; Lublin, H.; Knudsen, G. M.; Glenthoj, B. Decreased frontal serotonin $2 \mathrm{~A}$ receptor binding in antipsychoticnaive patients with first-episode schizophrenia. Arch.Gen.Psychiatry, 2010, 67, 9-16.

[111] Erritzoe, D.; Rasmussen, H.; Kristiansen, K. T.; Frokjaer, V. G.; Haugbol, S.; Pinborg, L.; Baare, W.; Svarer, C.; Madsen, J.; Lublin, H.; Knudsen, G. M.; Glenthoj, B. Y. Cortical and subcortical 5-HT2A receptor binding in neuroleptic-naive firstepisode schizophrenic patients. Neuropsychopharmacology, 2008, 33, 2435-2441.

[112] Nguyen, L.; Rigo, J. M.; Rocher, V.; Belachew, S.; Malgrange, B.; Rogister, B.; Leprince, P.; Moonen, G. Neurotransmitters as early signals for central nervous system development. Cell Tissue Res., 2001, 305, 187-202.

[113] Lawrie, S. M.; Whalley, H. C.; Abukmeil, S. S.; Kestelman, J. N.; Donnelly, L.; Miller, P.; Best, J. J.; Owens, D. G.; Johnstone, E. C. Brain structure, genetic liability, and psychotic symptoms in subjects at high risk of developing schizophrenia. Biological Psychiatry, 2001, 49, 811-823.

[114] Job, D. E.; Whalley, H. C.; McConnell, S.; Glabus, M.; Johnstone, E. C.; Lawrie, S. M. Voxel-based morphometry of grey matter densities in subjects at high risk of schizophrenia. Schizophr.Res., 2003, 64, 1-13.

[115] Chan, R. C.; Di, X.; McAlonan, G. M.; Gong, Q. Y. Brain anatomical abnormalities in high-risk individuals, first-episode, and chronic schizophrenia: an activation likelihood estimation metaanalysis of illness progression. Schizophr.Bull., 2011, 37, 177-188.

[116] Cannon, T. D.; Hennah, W.; van Erp, T. G.; Thompson, P. M. Lonnqvist, J.; Huttunen, M.; Gasperoni, T.; Tuulio-Henriksson, A.; Pirkola, T.; Toga, A. W.; Kaprio, J.; Mazziotta, J.; Peltonen, L. Association of DISC1/TRAX haplotypes with schizophrenia, reduced prefrontal gray matter, and impaired short- and long-term memory. Arch.Gen.Psychiatry, 2005, 62, 1205-1213.

[117] Arora, R. C.; Meltzer, H. Y. Serotonin2 (5-HT2) receptor binding in the frontal cortex of schizophrenic patients. J.Neural Transm.Gen.Sect., 1991, 85, 19-29.

[118] Dean, B.; Hayes, W. Decreased frontal cortical serotonin2A receptors in schizophrenia. Schizophr.Res., 1996, 21, 133-139.

[119] Burnet, P. W.; Eastwood, S. L.; Harrison, P. J. 5-HT1A and 5HT2A receptor mRNAs and binding site densities are differentially altered in schizophrenia. Neuropsychopharmacology, 1996, 15, 442-455.

[120] Kouzmenko, A. P.; Hayes, W. L.; Pereira, A. M.; Dean, B.; Burnet, P. W.; Harrison, P. J. 5-HT2A receptor polymorphism and steady state receptor expression in schizophrenia. Lancet, 1997, 349 , 1815-

[121] Dean, B.; Hayes, W.; Hill, C.; Copolov, D. Decreased serotonin2A receptors in Brodmann's area 9 from schizophrenic subjects. A pathological or pharmacological phenomenon? Mol.Chem.Neuropathol., 1998, 34, 133-145.

[122] Kouzmenko, A. P.; Scaffidi, A.; Pereira, A. M.; Hayes, W. L.; Copolov, D. L.; Dean, B. No correlation between A(-1438)G polymorphism in 5-HT2A receptor gene promoter and the density 
of frontal cortical 5-HT2A receptors in schizophrenia. Hum.Hered., 1999, 49, 103-105.

[123] Pralong, D.; Tomaskovic-Crook, E.; Opeskin, K.; Copolov, D.; Dean, B. Serotonin(2A) receptors are reduced in the planum temporale from subjects with schizophrenia. Schizophr.Res., 2000, $44,35-45$.

[124] Matsumoto, I.; Inoue, Y.; Iwazaki, T.; Pavey, G.; Dean, B. 5-HT2A and muscarinic receptors in schizophrenia: a postmortem study. Neurosci.Lett., 2005, 379, 164-168.

[125] Kang, K.; Huang, X. F.; Wang, Q.; Deng, C. Decreased density of serotonin $2 \mathrm{~A}$ receptors in the superior temporal gyrus in schizophrenia--a postmortem study. Progress in Neuropsychopharmacology and Biological Psychiatry, 2009, 33, 867871.

[126] Dean, B.; Hayes, W.; Opeskin, K.; Naylor, L.; Pavey, G.; Hill, C.; Keks, N.; Copolov, D. L. Serotonin2 receptors and the serotonin transporter in the schizophrenic brain. Behav.Brain Res., 1996, 73, $169-175$.

[127] Gonzalez-Maeso, J.; Ang, R. L.; Yuen, T.; Chan, P.; Weisstaub, N. V.; Lopez-Gimenez, J. F.; Zhou, M.; Okawa, Y.; Callado, L. F.; Milligan, G.; Gingrich, J. A.; Filizola, M.; Meana, J. J.; Sealfon, S. C. Identification of a serotonin/glutamate receptor complex implicated in psychosis. Nature, 2008, 452, 93-97.

[128] Dean, B.; Crossland, N.; Boer, S.; Scarr, E. Evidence for altered post-receptor modulation of the serotonin $2 \mathrm{a}$ receptor in schizophrenia. Schizophr.Res., 2008, 104, 185-197.

[129] Joyce, J. N.; Shane, A.; Lexow, N.; Winokur, A.; Casanova, M. F.; Kleinman, J. E. Serotonin uptake sites and serotonin receptors are altered in the limbic system of schizophrenics. Neuropsychopharmacology, 1993, 8, 315-336.

[130] Andree, T. H.; Mikuni, M.; Tong, C. Y.; Koenig, J. I.; Meltzer, H. Y. Differential effect of subchronic treatment with various neuroleptic agents on serotonin2 receptors in rat cerebral cortex. J.Neurochem., 1986, 46, 191-197.

[131] Wilmot, C. A.; Szczepanik, A. M. Effects of acute and chronic treatments with clozapine and haloperidol on serotonin (5-HT2) and dopamine (D2) receptors in the rat brain. Brain Res., 1989, 487, 288-298.

[132] O'Dell, S. J.; La Hoste, G. J.; Widmark, C. B.; Shapiro, R. M.; Potkin, S. G.; Marshall, J. F. Chronic treatment with clozapine or haloperidol differentially regulates dopamine and serotonin receptors in rat brain. Synapse, 1990, 6, 146-153.

[133] Mikuni, M.; Meltzer, H. Y. Reduction of serotonin-2 receptors in rat cerebral cortex after subchronic administration of imipramine, chlorpromazine, and the combination thereof. Life Sci., 1984, 34, 87-92.

[134] Burnet, P. W.; Chen, C. P.; McGowan, S.; Franklin, M.; Harrison, P. J. The effects of clozapine and haloperidol on serotonin-1 A, -2A and $-2 \mathrm{C}$ receptor gene expression and serotonin metabolism in the rat forebrain. Neuroscience, 1996, 73, 531-540.

[135] Tauscher, J.; Kapur, S.; Verhoeff, N. P.; Hussey, D. F.; Daskalakis, Z. J.; Tauscher-Wisniewski, S.; Wilson, A. A.; Houle, S.; Kasper, S.; Zipursky, R. B. Brain serotonin 5-HT(1A) receptor binding in schizophrenia measured by positron emission tomography and [11C]WAY-100635. Arch.Gen.Psychiatry, 2002, 59, 514-520.

[136] Bantick, R. A.; Montgomery, A. J.; Bench, C. J.; Choudhry, T.; Malek, N.; McKenna, P. J.; Quested, D. J.; Deakin, J. F.; Grasby, P. M. A positron emission tomography study of the 5-HT1A receptor in schizophrenia and during clozapine treatment. J.Psychopharmacol., 2004, 18, 346-354.

[137] Frankle, W. G.; Lombardo, I.; Kegeles, L. S.; Slifstein, M.; Martin, J. H.; Huang, Y.; Hwang, D. R.; Reich, E.; Cangiano, C.; Gil, R.; Laruelle, M.; Abi-Dargham, A. Serotonin 1A receptor availability in patients with schizophrenia and schizo-affective disorder: a positron emission tomography imaging study with [11C]WAY 100635. Psychophamacology (Berlin), 2006, 189, 155-164.

[138] Yasuno, F.; Suhara, T.; Ichimiya, T.; Takano, A.; Ando, T.; Okubo, Y. Decreased 5-HT1A receptor binding in amygdala of schizophrenia. Biological Psychiatry, 2004, 55, 439-444.

[139] Dean, B.; Tomaskovic-Crook, E.; Opeskin, K.; Keks, N.; Copolov, D. No change in the density of the serotonin $1 \mathrm{~A}$ receptor, the serotonin 4 receptor or the serotonin transporter in the dorsolateral prefrontal cortex from subjects with schizophrenia. Neurochem.Int., 1999, 34, 109-115.

[140] Lopez-Figueroa, A. L.; Norton, C. S.; Lopez-Figueroa, M. O.; Armellini-Dodel, D.; Burke, S.; Akil, H.; Lopez, J. F.; Watson, S.
J. Serotonin 5-HT1A, 5-HT1B, and 5-HT2A receptor mRNA expression in subjects with major depression, bipolar disorder, and schizophrenia. Biological Psychiatry, 2004, 55, 225-233.

[141] Burnet, P. W.; Eastwood, S. L.; Harrison, P. J. [3H]WAY-100635 for 5-HT1A receptor autoradiography in human brain: a comparison with $[3 \mathrm{H}] 8-\mathrm{OH}-\mathrm{DPAT}$ and demonstration of increased binding in the frontal cortex in schizophrenia. Neurochem.Int., 1997, 30, 565-574.

[142] Hashimoto, T.; Nishino, N.; Nakai, H.; Tanaka, C. Increase in serotonin 5-HT1A receptors in prefrontal and temporal cortices of brains from patients with chronic schizophrenia. Life Sci., 1991, 48, 355-363.

[143] Simpson, M. D.; Lubman, D. I.; Slater, P.; Deakin, J. F. Autoradiography with $[3 \mathrm{H}] 8-\mathrm{OH}-\mathrm{DPAT}$ reveals increases in 5$\mathrm{HT}(1 \mathrm{~A})$ receptors in ventral prefrontal cortex in schizophrenia. Biological Psychiatry, 1996, 39, 919-928.

[144] Sumiyoshi, T.; Stockmeier, C. A.; Overholser, J. C.; Dilley, G. E.; Meltzer, H. Y. Serotonin1A receptors are increased in postmortem prefrontal cortex in schizophrenia. Brain Res., 1996, 708, 209-214.

[145] Frankle, W. G.; Narendran, R.; Huang, Y.; Hwang, D. R.; Lombardo, I.; Cangiano, C.; Gil, R.; Laruelle, M.; Abi-Dargham, A. Serotonin transporter availability in patients with schizophrenia: a positron emission tomography imaging study with [11C]DASB. Biological Psychiatry, 2005, 57, 1510-1516.

[146] Dean, B.; Opeskin, K.; Pavey, G.; Naylor, L.; Hill, C.; Keks, N.; Copolov, D. L. [3H]paroxetine binding is altered in the hippocampus but not the frontal cortex or caudate nucleus from subjects with schizophrenia. J.Neurochem., 1995, 64, 1197-1202.

[147] Busatto, G. F.; Pilowsky, L. S.; Costa, D. C.; Ell, P. J.; David, A. S.; Lucey, J. V.; Kerwin, R. W. Correlation between reduced in vivo benzodiazepine receptor binding and severity of psychotic symptoms in schizophrenia. Am.J.Psychiatry, 1997, 154, 56-63.

[148] Abi-Dargham, A.; Laruelle, M.; Krystal, J.; D'Souza, C.; Zoghbi, S.; Baldwin, R. M.; Seibyl, J.; Mawlawi, O.; de, E. G.; Charney, D.; Innis, R. B. No evidence of altered in vivo benzodiazepine receptor binding in schizophrenia. Neuropsychopharmacology, 1999, 20, 650-661

[149] Verhoeff, N. P.; Soares, J. C.; D'Souza, C. D.; Gil, R.; Degen, K.; Abi-Dargham, A.; Zoghbi, S. S.; Fujita, M.; Rajeevan, N.; Seibyl, J. P.; Krystal, J. H.; van Dyck, C. H.; Charney, D. S.; Innis, R. B. [123I]Iomazenil SPECT benzodiazepine receptor imaging in schizophrenia. Psychiatry Research, 1999, 91, 163-173.

[150] Reynolds, G. P.; Stroud, D. Hippocampal benzodiazepine receptors in schizophrenia. J.Neural Transm.Gen.Sect., 1993, 93, 151-155.

[151] Kiuchi, Y.; Kobayashi, T.; Takeuchi, J.; Shimizu, H.; Ogata, H.; Toru, M. Benzodiazepine receptors increase in post-mortem brain of chronic schizophrenics. Eur.Arch.Psychiatry Neurol.Sci., 1989, 239, 71-78.

[152] Pandey, G. N.; Conley, R. R.; Pandey, S. C.; Goel, S.; Roberts, R. C.; Tamminga, C. A.; Chute, D.; Smialek, J. Benzodiazepine receptors in the post-mortem brain of suicide victims and schizophrenic subjects. Psychiatry Research, 1997, 71, 137-149.

[153] Benes, F. M.; Wickramasinghe, R.; Vincent, S. L.; Khan, Y.; Todtenkopf, M. Uncoupling of GABA(A) and benzodiazepine receptor binding activity in the hippocampal formation of schizophrenic brain. Brain Res., 1997, 755, 121-129.

[154] Dean, B.; Pavey, G.; McLeod, M.; Opeskin, K.; Keks, N.; Copolov, D. A change in the density of [(3)H]flumazenil, but not [(3)H]muscimol binding, in Brodmann's Area 9 from subjects with bipolar disorder. Journal of Affective Disorders, 2001, 66, 147-158.

[155] Takano, A.; Arakawa, R.; Ito, H.; Tateno, A.; Takahashi, H.; Matsumoto, R.; Okubo, Y.; Suhara, T. Peripheral benzodiazepine receptors in patients with chronic schizophrenia: a PET study with [11C]DAA1106. Int.J.Neuropsychopharmacol., 2010, 13, 943-950.

[156] Doorduin, J.; de Vries, E. F.; Willemsen, A. T.; de Groot, J. C.; Dierckx, R. A.; Klein, H. C. Neuroinflammation in schizophreniarelated psychosis: a PET study. J.Nucl.Med., 2009, 50, 1801-1807.

[157] Kurumaji, A.; Wakai, T.; Toru, M. Decreases in peripheral-type benzodiazepine receptors in postmortem brains of chronic schizophrenics. J.Neural Transm., 1997, 104, 1361-1370.

[158] Raghavendra Rao, V. L.; Dogan, A.; Bowen, K. K.; Dempsey, R. J. Traumatic brain injury leads to increased expression of peripheraltype benzodiazepine receptors, neuronal death, and activation of astrocytes and microglia in rat thalamus. Exp.Neurol., 2000, 161, 102-114. 
[159] Bressan, R. A.; Erlandsson, K.; Mulligan, R. S.; Gunn, R. N.; Cunningham, V. J.; Owens, J.; Ell, P. J.; Pilowsky, L. S. Evaluation of NMDA receptors in vivo in schizophrenic patients with [123I]CNS 1261 and SPET: preliminary findings. Ann.N.Y.Acad.Sci., 2003, 1003, 364-367.

[160] Pilowsky, L. S.; Bressan, R. A.; Stone, J. M.; Erlandsson, K.; Mulligan, R. S.; Krystal, J. H.; Ell, P. J. First in vivo evidence of an NMDA receptor deficit in medication-free schizophrenic patients. Mol.Psychiatry, 2006, 11, 118-119.

[161] Beneyto, M.; Kristiansen, L. V.; Oni-Orisan, A.; McCullumsmith, R. E.; Meador-Woodruff, J. H. Abnormal glutamate receptor expression in the medial temporal lobe in schizophrenia and mood disorders. Neuropsychopharmacology, 2007, 32, 1888-1902.

[162] Kerwin, R.; Patel, S.; Meldrum, B. Quantitative autoradiographic analysis of glutamate binding sites in the hippocampal formation in normal and schizophrenic brain post mortem. Neuroscience, 1990, 39, 25-32.

[163] Gao, X. M.; Sakai, K.; Roberts, R. C.; Conley, R. R.; Dean, B.; Tamminga, C. A. Ionotropic glutamate receptors and expression of $\mathrm{N}$-methyl-D-aspartate receptor subunits in subregions of human hippocampus: effects of schizophrenia. Am.J.Psychiatry, 2000, 157, 1141-1149.

[164] Toro, C.; Deakin, J. F. NMDA receptor subunit NRI and postsynaptic protein PSD-95 in hippocampus and orbitofrontal cortex in schizophrenia and mood disorder. Schizophr.Res., 2005, $80,323-330$

[165] Meador-Woodruff, J. H.; Healy, D. J. Glutamate receptor expression in schizophrenic brain. Brain Res.Brain Res.Rev., 2000, 31, 288-294.

[166] Noga, J. T.; Hyde, T. M.; Herman, M. M.; Spurney, C. F.; Bigelow, L. B.; Weinberger, D. R.; Kleinman, J. E. Glutamate receptors in the postmortem striatum of schizophrenic, suicide, and control brains. Synapse, 1997, 27, 168-176.

[167] Clinton, S. M.; Meador-Woodruff, J. H. Abnormalities of the NMDA Receptor and Associated Intracellular Molecules in the Thalamus in Schizophrenia and Bipolar Disorder. Neuropsychopharmacology, 2004, 29, 1353-1362.

[168] Dracheva, S.; Byne, W.; Chin, B.; Haroutunian, V. Ionotropic glutamate receptor mRNA expression in the human thalamus: absence of change in schizophrenia. Brain Res., 2008, 1214, 23-34.

[169] Ibrahim, H. M.; Hogg, A. J., Jr.; Healy, D. J.; Haroutunian, V.; Davis, K. L.; Meador-Woodruff, J. H. Ionotropic glutamate receptor binding and subunit mRNA expression in thalamic nuclei in schizophrenia. Am.J.Psychiatry, 2000, 157, 1811-1823.

[170] Raedler, T. J.; Knable, M. B.; Jones, D. W.; Urbina, R. A.; Gorey, J. G.; Lee, K. S.; Egan, M. F.; Coppola, R.; Weinberger, D. R. In vivo determination of muscarinic acetylcholine receptor availability in schizophrenia. Am.J.Psychiatry, 2003, 160, 118-127.

[171] Dean, B.; Crook, J. M.; Opeskin, K.; Hill, C.; Keks, N.; Copolov, D. L. The density of muscarinic M1 receptors is decreased in the caudate-putamen of subjects with schizophrenia. Mol.Psychiatry, 1996, $1,54-58$.

[172] Crook, J. M.; Dean, B.; Pavey, G.; Copolov, D. The binding of [3H]AF-DX 384 is reduced in the caudate-putamen of subjects with schizophrenia. Life Sci., 1999, 64, 1761-1771.

[173] Crook, J. M.; Tomaskovic-Crook, E.; Copolov, D. L.; Dean, B. Decreased muscarinic receptor binding in subjects with schizophrenia: a study of the human hippocampal formation. Biological Psychiatry, 2000, 48, 381-388.

[174] Crook, J. M.; Tomaskovic-Crook, E.; Copolov, D. L.; Dean, B. Low muscarinic receptor binding in prefrontal cortex from subjects with schizophrenia: a study of Brodmann's areas 8, 9, 10, and 46 and the effects of neuroleptic drug treatment. Am.J.Psychiatry, 2001, 158, 918-925.

[175] Dean, B.; McLeod, M.; Keriakous, D.; McKenzie, J.; Scarr, E. Decreased muscarinic(1) receptors in the dorsolateral prefrontal cortex of subjects with schizophrenia. Mol.Psychiatry, 2002, 7, 1083-1091.

[176] Mancama, D.; Arranz, M. J.; Landau, S.; Kerwin, R. Reduced expression of the muscarinic 1 receptor cortical subtype in schizophrenia. Am.J.Med.Genet.B Neuropsychiatr.Genet., 2003, 119, 2-6.

[177] Zavitsanou, K.; Katsifis, A.; Filomena, M.; Xu-Feng, H. Investigation of $\mathrm{M} 1 / \mathrm{M} 4$ muscarinic receptors in the anterior cingulate cortex in schizophrenia, bipolar disorder, and major depression disorder. Neuropsychopharmacology, 2004, 29, 619625.

[178] Deng, C.; Huang, X. F. Decreased density of muscarinic receptors in the superior temporal gyrus in schizophrenia. J.Neurosci.Res., 2005, 81, 883-890.

[179] Scarr, E.; Sundram, S.; Keriakous, D.; Dean, B. Altered hippocampal muscarinic $\mathrm{m} 4$, but not $\mathrm{m} 1$, receptor expression from subjects with schizophrenia. Biological Psychiatry, 2007, 61, 11611170 .

[180] Newell, K. A.; Zavitsanou, K.; Jew, S. K.; Huang, X. F. Alterations of muscarinic and GABA receptor binding in the posterior cingulate cortex in schizophrenia. Progress in Neuropsychopharmacology and Biological Psychiatry, 2007, 31, 225 233.

[181] Scarr, E.; Cowie, T. F.; Kanellakis, S.; Sundram, S.; Pantelis, C.; Dean, B. Decreased cortical muscarinic receptors define a subgroup of subjects with schizophrenia. Mol Psychiatry, 2009, 14, 10171023.

[182] Salah-Uddin, H.; Scarr, E.; Pavey, G.; Harris, K.; Hagan, J. J.; Dean, B.; Challiss, R. A.; Watson, J. M. Altered M(1) muscarinic acetylcholine receptor (CHRM1)-Galpha(q/11) coupling in a schizophrenia endophenotype. Neuropsychopharmacology, 2009, 34, 2156-2166.

[183] Gibbons, A. S.; Scarr, E.; Boer, S.; Money, T.; Jeon, W. J.; Felder, C.; Dean, B. Widespread decreases in cortical muscarinic receptors in a subset of people with schizophrenia. Int.J.Neuropsychopharmacol., 2012, 1-10.

[184] Scarr, E.; Keriakous, D.; Crossland, N.; Dean, B. No change in cortical muscarinic M2, M3 receptors or [35S]GTPgammaS binding in schizophrenia. Life Sci., 2006, 78, 1231-1237.

[185] Dean, B.; Crook, J. M.; Pavey, G.; Opeskin, K.; Copolov, D. L. Muscarinic1 and 2 receptor mRNA in the human caudate-putamen: no change in m1 mRNA in schizophrenia. Mol.Psychiatry, 2000, 5, 203-207.

[186] Dean, B.; Gray, L.; Keriakous, D.; Scarr, E. A comparison of M1 and M4 muscarinic receptors in the thalamus from control subjects and subjects with schizophrenia. Thalamus and Related Systems, 2004, 2, 287-295.

[187] Wong, D. F.; Kuwabara, H.; Horti, A. G.; Raymont, V.; Brasic, J.; Guevara, M.; Ye, W.; Dannals, R. F.; Ravert, H. T.; Nandi, A.; Rahmim, A.; Ming, J. E.; Grachev, I.; Roy, C.; Cascella, N. Quantification of cerebral cannabinoid receptors subtype 1 (CB1) in healthy subjects and schizophrenia by the novel PET radioligand [11C]OMAR. Neuroimage., 2010, 52, 1505-1513.

[188] Dean, B.; Sundram, S.; Bradbury, R.; Scarr, E.; Copolov, D. Studies on $[3 \mathrm{H}] \mathrm{CP}-55940$ binding in the human central nervous system: regional specific changes in density of cannabinoid-1 receptors associated with schizophrenia and cannabis use. Neuroscience, 2001, 103, 9-15.

[189] Zavitsanou, K.; Garrick, T.; Huang, X. F. Selective antagonist [3H]SR141716A binding to cannabinoid CB1 receptors is increased in the anterior cingulate cortex in schizophrenia. Progress in Neuro-psychopharmacology and Biological Psychiatry, 2004, 28, 355-360.

[190] Deng, C.; Han, M.; Huang, X. F. No changes in densities of cannabinoid receptors in the superior temporal gyrus in schizophrenia. Neurosci.Bull., 2007, 23, 341-347.

[191] Eggan, S. M.; Hashimoto, T.; Lewis, D. A. Reduced cortical cannabinoid 1 receptor messenger RNA and protein expression in schizophrenia. Arch.Gen.Psychiatry, 2008, 65, 772-784.

[192] Johns, A. Psychiatric effects of cannabis. Br.J.Psychiatry, 2001, 178, 116-122.

[193] Iwabuchi, K.; Ito, C.; Tashiro, M.; Kato, M.; Kano, M.; Itoh, M.; Iwata, R.; Matsuoka, H.; Sato, M.; Yanai, K. Histamine H1 receptors in schizophrenic patients measured by positron emission tomography. European Neuropsychopharmacology, 2005, 15, 185191.

[194] Nakai, T.; Kitamura, N.; Hashimoto, T.; Kajimoto, Y.; Nishino, N.; Mita, T.; Tanaka, C. Decreased histamine $\mathrm{H} 1$ receptors in the frontal cortex of brains from patients with chronic schizophrenia. Biological Psychiatry, 1991, 30, 349-356.

[195] Tamminga, C. A. Accelerating new knowledge in schizophrenia. Am.J.Psychiatry, 2008, 165, 949-951.

[196] Martinot, J. L.; Peron-Magnan, P.; Huret, J. D.; Mazoyer, B.; Baron, J. C.; Boulenger, J. P.; Loc'h, C.; Maziere, B.; Caillard, V.; Loo, H.; . Striatal D2 dopaminergic receptors assessed with 
positron emission tomography and [76Br]bromospiperone in untreated schizophrenic patients. Am.J.Psychiatry, 1990, 147, 4450.

[197] Schmitt, G. J.; Meisenzahl, E. M.; Frodl, T.; La, F. C.; Hahn, K.; Moller, H. J.; Dresel, S. Increase of striatal dopamine transmission in first episode drug-naive schizophrenic patients as demonstrated by [(123)I]IBZM SPECT. Psychiatry Research, 2009, 173, 183189.

Received: June 26, 2012

Revised: August 23, 2012

Accepted: September 14, 2012
[198] Hirvonen, J.; van Erp, T. G.; Huttunen, J.; Aalto, S.; Nagren, K.; Huttunen, M.; Lonnqvist, J.; Kaprio, J.; Cannon, T. D.; Hietala, J. Brain dopamine $\mathrm{d} 1$ receptors in twins discordant for schizophrenia. Am.J.Psychiatry, 2006, 163, 1747-1753.

[199] Asai, Y.; Takano, A.; Ito, H.; Okubo, Y.; Matsuura, M.; Otsuka, A.; Takahashi, H.; Ando, T.; Ito, S.; Arakawa, R.; Asai, K.; Suhara, T. GABAA/Benzodiazepine receptor binding in patients with schizophrenia using [11C]Ro15-4513, a radioligand with relatively high affinity for alpha5 subunit. Schizophr.Res., 2008, 99, 333-340. 